4

$9{ }^{2}$ Department of Earth Sciences, University of St. Andrews, St. Andrews, Scotland, UK,

15 Abstract: Neodymium isotope data on metalliferous mudstones (exhalites) and tuffs

16 from the Cambrian Lemarchant VMS deposit provide insights into the tectonic

17 environment of the Tally Pond volcanic belt, Canada. The Lemarchant samples have

$18 \varepsilon \mathrm{Nd}_{513}=-6.0$ to -1.8 , whereas associated volcanic rocks have $\varepsilon \mathrm{Nd}_{513}$ of +0.4 to +1.4 .

19 The more evolved values in the exhalites have not been reported yet; however, they

20 overlap the $\varepsilon \mathrm{Nd}$ of the underlying Ganderian Neoproterozoic Sandy Brook Group $\left(\varepsilon N d_{t}=\right.$

$21-6.5$ to -1.9$)$, and Crippleback Intrusive Suite $\left(\varepsilon \mathrm{Nd}_{\mathrm{t}}=-5.9\right.$ to -5.2$)$. The evolved $\mathrm{Nd}$

22 isotopic signatures suggest that the Tally Pond volcanic belt was formed upon Ganderian

23 arc basement, which itself was possibly built upon, or proximal to, the Gondwanan 
24 Amazonian margin. Erosion of older crustal material and Tally Pond volcanic belt

25 volcanic rocks, together with coeval eruption of the volcanic rocks, released Nd-rich

26 detritus into the water column. Uptake of eroded detrital and scavenged Nd resulted in

27 mixed Nd sources (juvenile and evolved), archived in the exhalites. The results of this

28 study are of significance not only for occurrences of exhalites within the Tally Pond

29 volcanic belt, but also have exploration implications for VMS districts globally.

33 Metalliferous mudstones (exhalites) are abundant in the Tally Pond volcanic belt, central

34 Newfoundland Appalachians, Canada, and are locally genetically associated with

35 volcanogenic massive sulphide (VMS) deposits (Swinden 1991; Squires \& Moore 2004).

36 The Tally Pond volcanic belt, which is part of the Dunnage Zone, Newfoundland,

37 Canada, belongs to the Cambrian ( $\sim 515 \mathrm{Ma})$ to Permian ( $275 \mathrm{Ma})$ Appalachian-

38 Caledonide mountain belt that hosts numerous VMS deposits, including the past-

39 producing Duck Pond and Boundary mines, and the precious metal-bearing Lemarchant

40 deposit (Fig. 1A-B; Williams 1979; Swinden 1988, 1991; Evans \& Kean 2002; Grenne \&

41 Slack 2003; Rogers et al. 2007; van Staal \&Barr 2011; Piercey et al. 2014; Hollis et al.

42 2015). The Tally Pond group ( $513-509 \mathrm{Ma})$ volcanic rocks and related massive sulphide

43 mineralization formed during arc rifting during the construction of the Cambrian to Early

44 Ordovician Penobscot Arc, which is known to be built upon Ganderian Neoproterozoic

45 ( $\sim 563 \mathrm{Ma})$ arc basement of the Crippleback Intrusive Suite and the coeval Sandy Brook

46 Group (Pollock et al. 2002; Zagorevski et al. 2007; Zagorevski et al.2010; Piercey et al. 
47 2014). In the Neoproterozoic and Early Cambrian Ganderia was located north-west of the

48 Gondwanan Amazonian margin (Fyffe et al. 2009; van Staal et al.2012; Murphy et al.

49 2014). The Penobscot arc represented the leading edge of Ganderia in a supra-subduction

50 zone setting and arc rifting was initiated due to slab roll-back along this margin (Jenner \&

51 Swinden 1993; Schulz et al. 2008; Murphy et al. 2014). The basement to the Ganderian

52 arc is not exposed; however, detrital zircon and $\mathrm{Nd}$ isotopic studies indicate the presence

53 of older crustal rocks that were derived from the Gondwanan Amazonian craton (Nance

54 et al. 2008; Schulz et al. 2008). Rifting of the Penobscot Arc led to the formation of

55 volcanogenic massive sulphide (VMS) mineralization and associated hydrothermal

56 sedimentary rocks of the Tally Pond group (Rogers et al. 2006; Copeland et al. 2009;

57 Zagorevski et al. 2010; Piercey et al.2014; Lode et al. 2016).

58 During rifting of the Penobscot arc there was extension, massive sulfide formation, and

59 the genesis of hydrothermal sedimentary rocks that formed from the deposition from

60 buoyant hydrothermal plumes from black smokers (Hekinian et al. 1993; Hannington et

61 al. 1995; German \& Von Damm 2003). These black smokers and associated

62 hydrothermal sedimentary rocks occur where hydrothermal fluids are focused along deep

63 synvolcanic faults in extensional settings (e.g., ocean ridges, rifted arcs, or backarc basin

64 spreading centres) (Fig. 2; Lydon 1984; Hannington et al. 2005; Gibson et al. 2007). The

65 hydrothermal fluids consist of modified seawater, which is entrained through oceanic or

66 rift-related continental crust, and are variably metal bearing with $\mathrm{Fe}, \mathrm{Mn}, \mathrm{Cu}, \mathrm{Pb}$, and $\mathrm{Zn}$,

67 as well as reduced sulphur and Si (Von Damm 1990; German \& Von Damm 2003;

68 Galley et al. 2007; Tivey 2007; Huston et al. 2010). The metals and other ligands are

69 generally derived from seawater (S) and leached from host rocks (e.g., metals, $\mathrm{Si} \pm \mathrm{S}$ ) (Fig. 
70 2; Hannington et al. 2005; Huston et al. 2011). Hydrothermal plume-derived Fe-

71 oxyhydroxides are efficient scavengers of trace metals (e.g., oxyanions such as $\mathrm{HPO}_{4}{ }^{2-}$,

$72 \mathrm{HVO}_{4}{ }^{2-}, \mathrm{CrO}_{4}{ }^{2-}, \mathrm{HAsO}_{4}{ }^{2-}$ ) and rare earth elements (REE) plus $\mathrm{Y}$ from seawater (Mills \&

73 Elderfield 1995; Rudnicki 1995). A rifted arc environment exposes rock units of different

74 ages, hence varying $\mathrm{Nd}$ isotopic signatures, which contribute detrital material to the

75 hydrothermal matter in the exhalative sedimentary rocks due to erosional and weathering

76 processes (Keto \& Jacobson 1988; Mills \& Elderfield 1995). Therefore, exhalites not

77 only record seawater REE (including Nd) but also the provenance components of the

78 detrital sources at the time of formation (Mills \& Elderfield 1995; Peter 2003; Lode et al.

79 2015).

80 By using various isotopic tracers, such as Nd isotopes, it is possible to decipher the

81 potential sources of various components in hydrothermal sedimentary rocks. The $\mathrm{Nd}$

82 isotopic system is specifically useful for understanding the relative roles of evolved

83 versus juvenile crust, and provides further insight into the tectonic environment and

84 provenance of the metalliferous mudstones, as it is robust and not significantly modified

85 by diagenetic, hydrothermal, and metamorphic processes (McCulloch \& Wasserburg

86 1978; McLennan et al. 2003). In addition, the separation of Sm-Nd in Earth's reservoirs

87 is particularly useful in delineating juvenile versus evolved crust and the time-integrated

88 sources of materials in Earth materials (McCulloch \& Wasserburg 1978; Rollinson 1993;

89 McLennan et al. 2003). The Tally Pond belt volcanic rocks have $\varepsilon N d$ signatures that are

90 typically positive, whereas their basement rocks, i.e., the rifted arc rocks of the

91 Neoproterozoic Crippleback Intrusive Suite and the Sandy Brook Group show more

92 evolved $\varepsilon N d$ values (McLennan et al. 1993; Rogers et al. 2006; Nance et al. 2008; 
93 McNicoll et al. 2010; Piercey et al. 2014). Given the level of preservation of stratigraphy

94 of the lithofacies in the Lemarchant deposit, including the metalliferous mudstones, this

95 deposit is an excellent location to understand the provenance of hydrothermal mudstones

96 in ancient rifted arcs. Correspondingly, the $\mathrm{Nd}$ isotopic signatures in the mudstones may

97 be useful in outlining their provenance and the potential contributions of local versus

98 basement versus distal sources in their genesis.

99 The purpose of this study is to: 1) determine the sources of $\mathrm{Nd}$ in the metalliferous

100 mudstones and massive sulphides of the Lemarchant deposit; and 2) because the Tally

101 Pond volcanic belt is formed upon Ganderian and possibly older basement rocks, to

102 evaluate the relative roles of mantle and evolved crustal inputs that contributed to the

103 Lemarchant hydrothermal sedimentary rocks using the Nd isotope compositions of

104 metalliferous mudstones.

105

\section{Regional Geology}

107 The Tally Pond volcanic belt is located within the Central Mobile Belt, Newfoundland,

108 Canada, which is part of the Cambrian ( $\sim 515 \mathrm{Ma})$ to Permian ( 275 Ma) Appalachian

109 mountain belt (Williams 1979; Swinden 1988; Rogers et al. 2007; van Staal \& Barr

110 2011). The Newfoundland Appalachians are divided into four tectonostratigraphical

111 zones (from west to east): Humber, Dunnage, Gander and Avalon zones (Fig. 1A;

112 Williams 1979; Swinden 1988, 1991). The Dunnage Zone represents the Central Mobile

113 Belt (Williams et al. 1988; Swinden 1991; Rogers et al. 2007). These zones result from

114 and were affected by the successive accretion of three micro-continental blocks during

115 the Early Palaeozoic to Middle Palaeozoic (i.e., Dashwoods, Taconic orogenesis; 
116 Ganderia, Salinic orogenesis; and Avalonia, Acadian orogenesis) and related interoceanic

117 arcs and backarcs (Swinden 1991; Zagorevski et al.2010). In the Palaeozoic (Middle

118 Cambrian to Ordovician), these ribbon-shaped micro-continental blocks separated from

119 Gondwana and Laurentia, forming peri-Gondwanan and peri-Laurentian terranes and

120 subsequently accreted to Laurentia creating the composite Laurentian margin (Rogers $e t$

121 al. 2007; Zagorevski et al. 2010; van Staal \& Barr 2011). The Exploits Subzone

122 represents two phases of arc-backarc formation, the Cambrian to Early Ordovician

123 Penobscot Arc and the Early to Middle Ordovician Victoria Arc (Zagorevski et al. 2010).

124 The Tally Pond volcanic belt and its VMS deposits (Duck Pond and Boundary mines;

125 Lemarchant deposit; Fig. 1B) are hosted in the lower Victoria Lake supergroup within the

126 Exploits Subzone, which is comprised of Cambrian to Ordovician volcanic and

127 sedimentary rocks (Dunning et al. 1991; Rogers et al. 2007; McNicoll et al. 2010; van

128 Staal \& Barr 2011). The Victoria Lake supergroup is further subdivided into six

129 assemblages (Zagorevski et al. 2010; Piercey et al. 2014), which are bounded by faults,

130 and are from east to west: 1) the Tally Pond group; 2) the Long Lake group; 3) the Tulks

131 group; 4) the Sutherlands Pond group; 5) the Pats Pond group; and 6) the Wigwam Pond

132 group; the Tulks, Long Lake, and Tally Pond groups are known to host VMS deposits.

133 These six tectonic assemblages yield $\mathrm{U}-\mathrm{Pb}$ zircon ages ranging from $\sim 513$ to $453 \mathrm{Ma}$

134 (Dunning et al. 1987; Evans et al. 1990; Dunning et al. 1991; Evans \& Kean 2002;

135 Zagorevski et al. 2007; McNicoll et al. 2010). Furthermore, the Tally Pond group is

136 informally subdivided into the felsic volcanic rock dominated Bindons Pond formation

137 (also referred to as Boundary Brook formation) and the mafic volcanic rock dominated

138 Lake Ambrose formation (Rogers et al. 2006). The latter contains island arc tholeiitic 
139 basalts to andesites with $\varepsilon \mathrm{Nd}_{511}$ of +3.1 (Dunning et al. 1991; Evans \& Kean 2002;

140 Rogers et al. 2006), whereas the former contains predominantly transitional to calc-

141 alkalic rhyolitic to dacitic rocks with $\varepsilon \mathrm{Nd}_{511}$ of +1.8 to +2.6 (Rogers et al. 2006; Piercey

142 et al. 2014). The Cambrian felsic volcanic rocks of the Bindons Pond formation contain

143 inherited zircons with Neoproterozoic U-Pb ages of $563 \mathrm{Ma}$ (McNicoll et al. 2010).

144

\section{Deposit Geology and Lithofacies}

146 The Lemarchant VMS deposit is hosted within the Bindons Pond formation and is capped

147 by a $<1$ to $20 \mathrm{~m}$ thick layer of metalliferous mudstones occurring at the contact between

148 the Bindons Pond and Lake Ambrose formations (Fig. 3A; Copeland et al. 2009; Fraser

149 et al. 2012; Lode et al. 2015). These sulphide-rich metalliferous mudstones extend

150 discontinuously around the massive sulphides for one to four kilometres (Copeland et al.

151 2009; Fraser et al.2012; Lode et al. 2015). Three main types of exhalative mudstones

152 occur at the Lemarchant deposit: 1) mudstones immediately on top of massive sulphide

153 mineralization between the felsic and mafic volcanic rocks (exhalative mudstone-massive

154 sulphide (EMS)-type; Fig. 3A-C, G-H); 2) mudstones extending laterally outwards from

155 mineralization, but at the same stratigraphical level and without immediate association

156 with mineralization (felsic-exhalative mudstone-mafic (FEM)-type; Fig. 3D); or 3)

157 interflow mudstones within the hanging wall basaltic rocks (interflow exhalative

158 mudstone (IFE)-type; Fig. 3E). Interflow mudstones occur commonly within 15 meters

159 above the massive sulphide mineralization, but are present up to 70 meters above the ore

160 horizon. Independent of their stratigraphical positions, the mudstones are brown to black,

161 graphite-rich, finely laminated, and contain fine carbonaceous/organic-rich laminae that 
162 are intercalated with siliciclastic, volcaniclastic and/or amorphous kidney-shaped

163 chert \pm apatite layers (Fig. 3C, F). The main sulphide phases are pyrite (framboidal,

164 massive and euhedral) and pyrrhotite, with minor marcasite, chalcopyrite, sphalerite,

165 arsenopyrite and galena. Contents of chalcopyrite, sphalerite, and galena increase

166 proximal to mineralization. The sulphides occur both parallel to bedding, and in later

167 stage, stringer-like veins (Fig. 3A, D-E).

168

169 Methodology

170 Sampling, methods, and quality control and quality assurance ( $Q A / Q C)$

171 Samples were collected during stratigraphical mapping and drill core logging of the

172 Lemarchant deposit from drill holes that have metalliferous mudstones and include the

173 Lemarchant Main Zone, the Northwest and 24 zones, as well as the North and South

174 targets (Fig. 4A). Samples were taken from representative exhalative mudstone types

175 (EMS, FEM, and IFE), tuff, and surrounding lithological mafic and felsic volcanic units.

176 The whole rock lithogeochemical data were previously evaluated and presented in Lode

177 et al. (2015), including analytical methods and QA/QC for lithogeochemical data.

178 Lithogeochemical data are reproduced here only to compare to $\mathrm{Nd}$ isotope results.

179 Neodymium isotopes

180 Twelve representative samples of the Lemarchant mudstones were selected for $\mathrm{Nd}$

181 isotopic determinations from the three mudstone types and tuffs that are intercalated with

182 the mudstones. These samples were chosen to cover both the horizontal and vertical

183 distributions of all mudstones types and tuff occurring in the Lemarchant area.

184 Additionally, one least altered sample of the felsic and mafic volcanic rocks (Fig. 3G-H) 
185 were selected for analyses, and for comparison to mudstone samples. Samarium and $\mathrm{Nd}$

186 isotopic compositions were measured at Memorial University using a multicollector

187 Finnigan MAT 262 thermal ionization mass spectrometer (TIMS) in static and dynamic

188 acquiring modes. Samples for Nd analyses were prepared using the methods of Fisher $e t$

189 al. (2011) from whole-rock powders using a multi-acid ( $\mathrm{HF}, \mathrm{HNO}_{3}$, and $\left.\mathrm{HCl}\right)$

190 dissolution-evaporation process following methods. Separation of Sm and Nd was

191 obtained using conventional two-step column chemical methods (Fisher et al. 2011).

192 Accuracy and precision for the Nd analyses were determined using the standards JNdi-1

193 and BCR-2 as reference materials following methods described in Fisher et al. (2011).

194 The JNdi-1 and BCR-2 standards have following reported values: ${ }^{143} \mathrm{Nd} /{ }^{144} \mathrm{Nd}=$

1950.512115 and ${ }^{143} \mathrm{Nd} /{ }^{144} \mathrm{Nd}=0.512633$, respectively (Tanaka et al. 2000; Raczek et al.

196 2003). Standards were run every 11 samples with each analytical batch. Additionally,

197 blanks were utilized during each analytical run to test contamination; none was detected.

198 Precision was determined using the percent relative standard deviation (\%RSD) on the

199 replicate analyses of the reference materials, and accuracy was determined using percent

200 relative difference $(\% \mathrm{RD})$ from accepted values. Analyses for the Lemarchant samples

201 have an average $0.0013 \% \mathrm{RSD}$ for ${ }^{143} \mathrm{Nd} /{ }^{144} \mathrm{Nd}$ and $0.00055 \% \mathrm{RD}$ for ${ }^{143} \mathrm{Nd} /{ }^{144} \mathrm{Nd}$.

202 The results herein are presented using the epsilon notation $(\varepsilon N d)$ and calculated for a

203 formation age of $513 \mathrm{Ma}$, the U-Pb age of the host stratigraphy as reported by Dunning et

204 al.(1991); data are presented in Table 1 and Figures 4B, 5A-B, and Figure 8. $\varepsilon \mathrm{Nd}_{513}$ was

205 calculated by $\varepsilon \mathrm{Nd}_{\mathrm{t}}=\left({ }^{143} \mathrm{Nd} /{ }^{144} \mathrm{Nd}_{\text {rock, } \mathrm{t}} /{ }^{143} \mathrm{Nd} /{ }^{144} \mathrm{Nd}_{\mathrm{CHUR}, \mathrm{t}}\right) \times 10^{4}$ after Rollinson (1993)

206 and $f^{\mathrm{Sm} / \mathrm{Nd}}=\left[\left({ }^{147} \mathrm{Sm} /{ }^{144} \mathrm{Nd} d_{\text {sample,t }}\right) /\left({ }^{147} \mathrm{Sm} /{ }^{144} \mathrm{Nd} \mathrm{CHUR}_{\mathrm{t}, \mathrm{t}}\right)-1\right]$ after McLennan et al. $(1990)$.

207 Chondrite uniform reservoir (CHUR) values utilized in this study are ${ }^{143} \mathrm{Nd} /{ }^{144} \mathrm{Nd}$ of 
0.512638 and a ${ }^{147} \mathrm{Sm} /{ }^{144} \mathrm{Nd}$ of 0.1967 (Hamilton et al. 1983; Rollinson 1993). Depleted

209 mantel model ages $\left(T_{\mathrm{DM}}\right)$ were calculated using depleted mantle values of ${ }^{144} \mathrm{Nd} /{ }^{144} \mathrm{Nd}=$

$210 \quad 0.513163$ and ${ }^{147} \mathrm{Sm} /{ }^{144} \mathrm{Nd}=0.2137$, and a decay constant of $\lambda=6.54 \times 10^{-12}$ (DePaolo

211 1981).

212 Results

213 Neodymium isotopic systematics. The Lemarchant mudstones $(\mathrm{n}=10)$, have

$214 \varepsilon \varepsilon \mathrm{Nd}_{513}=-6.0$ to -1.8 and $T_{\mathrm{DM}}=1.63$ to $3.05 \mathrm{Ga}$ (Table 1 ). Overall, the three types of

215 Lemarchant mudstones $(\mathrm{EMS}=$ proximal; FEM $=$ distal; IFE $=$ interflow $)$ have similar

$216 \varepsilon \mathrm{Nd}_{513}$ values; however, the EMS-type have slightly lower $\varepsilon \mathrm{Nd}_{513}$ values and range from

$217-5.6$ to -4.1 with an average of -4.8 , the FEM-type are less evolved and range from

$218 \varepsilon \mathrm{Nd}_{513}=-4.0$ to -3.2 with an average of -3.7 , and the IFE-type has the widest range of

$219 \varepsilon \mathrm{Nd}_{513}=-6.0$ to -1.8 and average of -3.9 (Table 1; Fig. 4B, 5A-B). The Lemarchant tuff

220 samples $(\mathrm{n}=2)$ have $\varepsilon \mathrm{Nd}_{513}=-5.7$ to -4.7 with an average of -5.2 and $T_{\mathrm{DM}}=1.75$ to

$2211.81 \mathrm{Ga}$. In $\varepsilon N d$ versus $\mathrm{Th} / \mathrm{Sc}$ space the Lemarchant mudstones and tuff have $\mathrm{Th} / \mathrm{Sc}$ ratios

222 of 0.06 to 1.93 and fall between the arc andesite fields, with samples that have greater

$223 \mathrm{Th} / \mathrm{Sc}$ containing lower $\varepsilon \mathrm{Nd}$ values like the upper crust (Fig. 5A). These more evolved

224 samples also trend towards the field of the 563 Ma Crippleback Intrusive Suite and Sandy

225 Brook Group crustal basement rocks (recalculated here at 513 Ma for comparison; Fig.

226 5A). The Lemarchant felsic and mafic volcanic rock measured in this study (one each)

227 have $\varepsilon \mathrm{Nd}_{513}=+0.4$ and a $T_{\mathrm{DM}}=1.47 \mathrm{Ga}$, and $\varepsilon \mathrm{Nd}_{513}=+1.4$ and a $T_{\mathrm{DM}}=1.74 \mathrm{Ga}$,

228 respectively, and plot in the field for arc rocks (Table 1; Fig. 5B). These values for the

229 Lemarchant volcanic rocks are similar to values reported by Rogers et al. (2006) and

230 McNicoll et al. (2010) for felsic and mafic volcanic rocks of the Tally Pond volcanic belt, 
231 including samples from the 'Upper Block' and the 'Mineralized Block' of the Duck Pond 232 deposit (Fig. 5B).

233 The $f^{\mathrm{Sm} / \mathrm{Nd}}$ reflects the fractional deviation of ${ }^{147} \mathrm{Sm} /{ }^{144} \mathrm{Nd}$ from CHUR in parts per $10^{4}$

234 because of light rare earth element enrichment (i.e., lower $\mathrm{Sm} / \mathrm{Nd}$ ) during igneous

235 differentiation processes (McLennan et al. 2003). Accordingly, in $f^{\mathrm{Sm} / \mathrm{Nd}}-\varepsilon \mathrm{Nd}$ space (Fig.

236 5B) the Lemarchant mudstone and tuff samples have more evolved $\varepsilon \mathrm{Nd}_{513}$ values than the

237 Lemarchant volcanic rocks, and are overall comparable in $\varepsilon N d$ to values reported by

238 Rogers et al. (2006) for the Neoproterozoic Crippleback quartz monzonite and Sandy

239 Brook Group rhyolite. However, the Lemarchant mudstone and tuff samples have $f^{\mathrm{Sm} / \mathrm{Nd}}$

240 higher than the Neoproterozoic Crippleback quartz-monzonite and Sandy Brook Group

241 rhyolite and trend towards those of the Tally Pond group volcanic rocks (Fig. 5B;

242 McLennan et al. 2003). The $\varepsilon N d$ values of the Lemarchant mudstone and tuff samples do

243 not show any spatial variations throughout the zones of the deposit and/or with depth in

244 the stratigraphy in the Lemarchant area (Fig. 4A-B). The $T_{\mathrm{DM}}=1.63$ to $3.05 \mathrm{Ga}$ of the

245 Lemarchant mudstones are older than reported values for the coeval felsic volcanic rocks

246 of the 'Upper Block' and 'Mineralized Block' at Duck Pond of 1.06 and $1.35 \mathrm{Ga}$, and

$2470.95 \mathrm{Ga}$, respectively (McNicoll et al. 2010), and those of the Crippleback Intrusive Suite

248 (1.26 and $1.35 \mathrm{Ga}$ ) and the Sandy Brook Group (1.15 to $1.34 \mathrm{Ga})$ (Rogers et al. 2006; this 249 study).

250 Immobile element systematics: Volcanic rocks of the Tally Pond group that are

251 associated with the hydrothermal sedimentary rocks and volcanic and igneous rocks of

252 the Sandy Brook Group and Crippleback Intrusive Suites are shown on the immobile

253 element $\mathrm{Zr} / \mathrm{Ti}-\mathrm{Nb} / \mathrm{Y}$ classification diagram by Winchester and Floyd (1977) and Pearce 
254 (1996) in Figure 6a. This diagram enables to discriminate and identify rock types,

255 independently from the degree of alteration (Winchester \& Floyd 1977; Pearce 1996).

256 The volcanic rocks from the Lemarchant deposit are subalkaline basaltic andesites, with

257 the more felsic rocks trending towards dacite boundary, and the more mafic rocks

258 trending towards the basalt boundary (Fig. 6A). Because of the limited sample number

259 for volcanic rocks from this study, fields from Cloutier et al. (in press) were added for

260 felsic, intermediate, and mafic volcanic rocks from the Lemarchant deposit (Fig. 6A).

261 Additionally, samples for Tally Pond belt felsic and mafic volcanic rocks, the Sandy

262 Brook Group rhyolite and basalt and Crippleback quartz monzonite of Rogers (2004) and

263 Rogers et al (2006) were also added for comparison. Chemically, the volcanic rocks of

264 Lemarchant show a wide distribution, with felsic-dominated rhyolite-dacites of the

265 Bindons Pond formation as well as intermediate andesite-basaltic andesites and mafic

266 rocks of the Lake Ambrose formation (Cloutier et al. in press). The alteration-

267 independent Nb-Y diagram after Pearce et al. (1984), which discriminates the general

268 tectonic settings, shows that the Tally Pond belt volcanic rocks plot predominantly in the

269 volcanic arc field (Fig. 6B), which is consistent with potential source rocks for the detrital

270 constituent in the hydrothermal sedimentary rocks and regional models for the Tally Pond

271 group (e.g., Rogers et al. 2007; Piercey et al. 2014).

272

\section{Discussion}

274 Provenance, tectonic setting, and the role of crustal input

275 The Tally Pond volcanic belt represents the oldest magmatism of the Penobscot Arc and

276 was developed during phases of arc rifting at the leading edge of the Ganderian margin 
277 (Rogers et al. 2006; Zagorevski et al. 2010; Piercey et al. 2014).

278 Penecontemporaneously, further rifting on the trailing edge of Ganderia, led to the

279 formation of the Ellsworth belt ( $\sim 509-505 \mathrm{Ma})$ of coastal Maine and New Brunswick

280 representing the separation of Ganderia from the Gondwanan Amazonian margin (Fyffe

281 et al. 2009; van Staal et al. 2012). The volcanic rocks of the Ellsworth terrane comprise

282 tholeiitic basalts and rhyolites with $\varepsilon \mathrm{Nd}_{500} \mathrm{Ma}$ values ranging from +5.6 to +8.6 , but also

283 calc-alkaline rhyolite (R-1 Rhyolite) that yielded $\varepsilon \mathrm{Nd}_{500}$ Ma values near zero (Schulz et al.

284 2008). The latter are similar to $\varepsilon N d$ values of felsic and mafic volcanic rock samples from

285 the Tally Pond belt (Bindons Pond and Lake Ambrose formations) of this study ( $\varepsilon \mathrm{Nd}=$

$286+1.4$ and +0.4 , respectively), which are comparable with values that were previously

287 reported for the Tally Pond volcanic rocks (Fig. 5B; Rogers et al. 2006; Zagorevski et al.

288 2010). This illustrates that the Lake Ambrose formation basalts have predominantly

289 juvenile signatures $\left(\varepsilon \mathrm{Nd}_{511 \mathrm{Ma}}=+3\right.$; Rogers et al. 2006 and this study), whereas Bindons

290 Pond formation rhyolites and dacites have less juvenile values $\left(\varepsilon \mathrm{Nd}_{511 \mathrm{Ma}}=+1.8\right.$ and +2.6$)$

291 (Rogers et al. 2006; Zagorevski et al. 2010). There is a noticeable difference in $\varepsilon \mathrm{Nd}_{513} \mathrm{Ma}$

292 values between the sedimentary and volcanic rocks of the Lemarchant deposit, however.

293 In general, the mudstones and tuffs have lower $\varepsilon \mathrm{Nd}_{513}$ values ranging from -6.0 to -1.8

294 (Fig. 5A-B), similar to the Sandy Brook Group rhyolite $\varepsilon \mathrm{Nd}_{513 \mathrm{Ma}}=-6.5$ to -1.9 , as well

295 as those of the Crippleback Intrusive Suite $\varepsilon \mathrm{Nd}_{513 \mathrm{Ma}}=-5.9$ to -5.2 (Rogers et al. 2006).

296 Moreover, the Lemarchant mudstones have similar $\varepsilon \mathrm{Nd}_{513}$ Ma values throughout the

297 sections of the Lemarchant Main Zone, the Northwest and 24 zones, and the North Target

298 (Fig. 4A-B), albeit proximal Lemarchant mudstones (EMS-type) have more evolved

$299 \varepsilon \mathrm{Nd}_{513}$ values than the more distal mudstones (FEM-type; Figs. 4A-B). 
300 There are a number of potential Nd sources in hydrothermal mudstones, including

301 seawater-derived/scavenged, detrital, and hydrothermally-derived components (Goldstein

302 et al. 1984; Mills et al. 1993; Mills \& Elderfield 1995). Scavenging of REE from

303 seawater occurs during mixing of the hydrothermal fluids with seawater, where

304 oxyanions $\left(\mathrm{HPO}_{4}{ }^{2-}, \mathrm{HVO}_{4}{ }^{2-}, \mathrm{CrO}_{4}{ }^{2-}, \mathrm{HAsO}_{4}{ }^{2-}\right)$, trace elements, and rare earth elements

305 (REE, including Nd) are scavenged from seawater onto Fe-oxyhydroxides, and

306 subsequently deposited on the mount flanks and in topographic depressions around the

307 hydrothermal vent site in a rift-graben or caldera basin (de Baar et al. 1988; Rudnicki

308 1995; German \& Von Damm 2003; Peter 2003). Nd isotopic signatures measured from

309 modern seawater show a wide range that indicate that continental $\mathrm{Nd}$ is the predominant

310 source of REE in modern seawater resulting in different $\mathrm{Nd}$ values within the main water

311 masses/oceans (Goldstein et al. 1984; Bertram \& Elderfield 1993; Tachikawa et al.

312 2003). Thus, exposure of crustal basement during arc rifting would bring crustal-derived

313 evolved Nd into the ambient seawater, together with $\mathrm{Nd}$ derived from the continuously

314 erupting and erosion of the more juvenile Cambrian Tally Pond volcanic rocks. The $\mathrm{Nd}$ is

315 contributed to the $\mathrm{Nd}$ budget of hydrothermal sediment either dissolved or as detrital

316 particles, and via adsorption onto hydrothermally-derived particles, such as Fe-

317 oxyhydroxides (Wood \& Williams-Jones 1994; Mills \& Elderfield 1995; Rudnicki 1995;

318 Chavagnac et al.2005). In contrast, hydrothermal $\mathrm{Nd}$ is a minimal component in

319 hydrothermal sediment, mostly because REE are in extremely low concentrations in

320 seafloor hydrothermal fluids and initial hydrothermal Nd signatures in the hydrothermal

321 sediment are often rapidly overprinted by Nd scavenged from seawater (Elderfield 1988;

322 Mills et al. 1993; Mills \& Elderfield 1995). Most hydrothermal sediment contains up to 
$323 \sim 80 \%$ hydrothermally-derived matter (i.e., derived directly from the fluid and scavenged

324 from seawater), whereas the remainder consists of sedimentary detritus, including

325 volcaniclastic and epiclastic material and windblown dust, which are also possible $\mathrm{Nd}$

326 sources in metalliferous sediments (Boström et al. 1972; Boström 1973; Cavanagh et al.

327 2005; Goldstein et al. 1984).

328 Considering these processes and potential Nd sources, it is noticeable that even though

329 the Lemarchant hydrothermal sediments predominantly consist of hydrothermally-

330 derived matter (e.g., $\mathrm{Zn}-\mathrm{Pb}-\mathrm{Cu}-\mathrm{Fe}-\mathrm{S}$ ), their $\mathrm{Nd}$ budget contains only minor

331 hydrothermally-derived Nd. The dilution of hydrothermal fluids by seawater, scavenging

332 processes, and contributions of detrital matter generally annihilates the initial

333 hydrothermal Nd signatures in hydrothermal sediments (Mills \& Elderfield 1995).

334 Because of the restricted nature of a rifted arc basin, where predominantly locally

335 occurring provenance rocks (i.e., Tally Pond volcanic rocks, Crippleback Intrusive Suite

336 and Sandy Brook Group basement rocks) are eroded, this locally-derived detrital Nd is

337 subsequently archived in the hydrothermal sedimentary rocks within the basin (Figs. 7A-

$338 \mathrm{~B}, 8)$. The Nd in these hydrothermal sediments was derived predominantly from

339 scavenging and detrital matter, which explains their evolved Nd signatures; signatures

340 that are not present in the more juvenile Tally Pond volcanic rocks. Furthermore, it is

341 suggested that the more evolved $\mathrm{Nd}$ signatures of the proximal mudstones represent early

342 stages of arc-rifting, which were dominated by erosion of the rifted Neoproterozoic

343 Ganderian and possibly older crustal basement, whereas the more distal mudstones reflect

344 greater contributions from the continuously erupting and erosion of the more juvenile

345 Cambrian Tally Pond group volcanic rocks (Fig. 7A-B). 
346 The presence of Neoproterozoic Ganderian arc rocks (Crippleback Intrusive Suite and

347 coeval Sandy Brook Group) beneath the Tally Pond volcanic belt is indicated by

348 inherited zircons (563 Ma) in the Cambrian felsic volcanic rocks of the Tally Pond belt

349 (Rogers et al. 2006; Rogers et al. 2007; McNicoll et al. 2010; Zagorevski et al. 2010).

350 Neoproterozoic ( $\sim 553 \mathrm{Ma})$ inherited zircon ages are also known from the Pats Pond

351 group ( $\sim 487 \mathrm{Ma})$, which also have Mesoproterozoic (0.9-1.2 Ga) xenocrystic zircons

352 (Zagorevski et al.2007, Zagorevski et al.2010). Plutonic and gneissic boulders, as well

353 as sedimentary rocks from the Ellsworth Formation of coastal Maine and New Brunswick

354 contained small populations of Mesoproterozoic, Palaeoproterozoic, and Archean zircons

355 up to $3.23 \mathrm{Ga}$, but with a dominant population between 1.07 to $1.61 \mathrm{Ga}$ (Hibbard et al.

356 2007; Schulz et al.2008; Fyffe et al. 2009; van Staal et al. 2012). These inherited zircon

357 patterns are consistent for a location of Ganderia along the Gondwanan Amazonian

358 margin (Fyffe et al. 2009; van Staal et al. 2012). The Mesoproterozoic to Archean $T_{\mathrm{DM}}$

359 model ages and $\mathrm{Nd}$ isotopic data of the Lemarchant mudstones (1.63 to $3.05 \mathrm{Ga}$ ) together

360 with the detrital zircon populations and the Nd signatures of the Tally Pond volcanic

361 rocks, as well as of the Crippleback Intrusive Suite and Sandy Brook Group, indicate an

362 Amazonian provenance, which suggests that the Tally Pond belt also evolved along this

363 margin (Fig. 8; Zagorevski et al. 2007; Pollock et al. 2011; van Staal \& Barr 2011; van

364 Staal et al. 2012).

365 Significant input from crustal material is further supported by the $\mathrm{Pb}$ isotopic data of the

366 Lemarchant deposit and other massive sulphide occurrences in the Tally Pond belt

367 (Swinden \& Thorpe 1984; Pollock \& Wilton 2001; Gill 2015; Lode et al. 2017).

368 Volcanogenic massive sulphides and associated hydrothermal sediments have $\mathrm{Pb}$ sources 
369 that derive their $\mathrm{Pb}$ predominantly from leaching of basement rocks, which may include

370 different reservoirs (Franklin et al. 1981; Swinden \& Thorpe 1984; Tosdal et al. 1999;

371 Ayuso et al. 2003). Lead isotopic data measured in-situ on galena hosted within sulphides

372 in the hydrothermal sediments using secondary ion mass spectrometry (SIMS), suggested

373 hydrothermally- and detritally-derived $\mathrm{Pb}$ sources (Lode et al. 2017). Especially more

374 vent distal mudstones showed more radiogenic detritally $\mathrm{Pb}$ contributions, which were

375 characterised by more radiogenic ${ }^{206} \mathrm{~Pb} /{ }^{204} \mathrm{~Pb}$ and ${ }^{208} \mathrm{~Pb} /{ }^{204} \mathrm{~Pb}$ ratios (Mills \& Elderfield

376 1995; Lode et al. 2017).

377 Altogether, the $\mathrm{Nd}$ and $\mathrm{Pb}$ isotopic data support that older crustal basement plays a role in

378 hydrothermal activity, either through direct leaching $(\mathrm{Pb})$, detrital $(\mathrm{Pb}+\mathrm{Nd})$, or via

379 adsorption/deposition from the water column (Nd). Furthermore, trace element signatures

380 of the Tally Pond volcanic rocks and provenance-related immobile element systematics

381 of the metalliferous mudstones are consistent with a formation in a volcanic arc

382 environment, such as a graben/caldera in a rifted continental arc, or an arc proximal to

383 continental crust (Rogers et al. 2006; Zagorevski et al. 2010; Piercey et al. 2014).

384 Therefore, the metalliferous mudstones that precipitate in a rifted arc basin/caldera setting

385 record the provenance components of the lithologies present in the basin and may be

386 useful for palaeogeographic reconstructions and additionally provide means to determine

387 the source of metals that contributed to the formation of the genetically associated

388 massive sulphides.

389

390 Conclusions 
391 It is proposed that the volcanogenic massive sulphides of the Lemarchant deposit and

392 related exhalative metalliferous mudstones that are associated with felsic, intermediate,

393 and mafic volcanic rocks are formed from fluids that ascend along deep synvolcanic

394 faults in a rifted arc basin. Eruption and erosion of the Tally Pond belt volcanic rocks that

395 were formed in this rift-related graben/caldera setting, added juvenile $\mathrm{Nd}$ to the system.

396 The hydrothermal sediments precipitate in an environment, where Ganderian arc rocks of

397 the Crippleback Intrusive Suite and the coeval Sandy Brook Group was exposed and

398 eroded, which contributed evolved crustal $\mathrm{Nd}$ to the ambient seawater. Based on detrital

399 zircon and $\mathrm{Nd}$ isotopic studies it is further suggested that unexposed older crustal

400 basement of the Gondwanan Amazonian margin beneath the Ganderian arc rocks

401 additionally contributed evolved $\mathrm{Nd}$ to the $\mathrm{Nd}$ budget in the metalliferous mudstones.

402 The precipitating hydrothermal metalliferous mudstones record the mixed, i.e., evolved

403 and juvenile, $\varepsilon N d$ signatures. Furthermore, the hydrothermal sediments have more

404 evolved $\varepsilon N d$ systematics than the spatially associated Tally Pond belt volcanic rocks

405 indicating the presence of eroded older crustal material that did not significantly

406 contribute to the volcanic rocks. Overall, the Nd isotopic compositions, as well as the

407 lithogeochemical data, of the Lemarchant metalliferous mudstones and suggests that the

408 Lemarchant deposit hydrothermal mudstones record formation within a rifted arc

409 environment built upon Ganderian (exposed) and Gondwanan Amazonian (unexposed)

410 crustal basement, consistent with existing models for the Tally Pond group.

411

\section{Acknowledgements}

413 Kind support was provided by Dianne and Charlie Fost, Michael Vande Guchte, 414 Alexandria Marcotte, and Gerry Squires from Paragon Minerals Corporation (a 100\%- 
415 owned subsidiary of Canadian Zinc Corporation). The authors would further like to thank

416 Keir Hiscock, Pam King, Sherry Strong, Anne Westhues, as well as Luke Beranek and

417 Greg Dunning for the helpful reviews and Inês Nobre Silva for general discussions, help, 418 and support.

\section{$420 \quad$ Funding information}

421 Research funded by the Canadian Mining Research Organization (CAMIRO, Project 422 08E04) and grants of the Natural Sciences and Engineering Research Council of Canada 423 (NSERC): NSERC Discovery Grant - 249695-2011; NSERC IRC Grant - 408433-09; 424 NSERC CRD Grant - CAMIRO Project - CRDPJ 387592-09; RDC and a grant of the 425 Research and Development Corporation of Newfoundland and Labrador (RDC) RDC 426 IRIF for IRC - 5003.121.001 to Dr. Stephen Piercey. Research was also funded by the 427 NSERC-Altius Industrial Research Chair in Mineral Deposits, funded by NSERC, Altius 428 Resources Inc.

429

\section{References}

Ayuso, R.A. \& Schulz, K.J. 2003. Nd-Pb-Sr isotope geochemistry and origin of the Ordovician Bald Mountain and Mount Chase massive sulfide deposits, northern Maine. Economic Geology Monographs, 11, 611-630.

Bertram, C.J. \& Elderfield, H. 1993. The geochemical balance of the rare earth elements and neodymium isotopes in the oceans. Geochimica et Cosmochimica Acta, 57, 19571986.

Chavagnac, V., German, C.R., Milton, J.A. \& Palmer, M.R. 2005. Sources of REE in sediment cores from the Rainbow vent site ( $\left.36^{\circ} 14^{\prime} \mathrm{N}, \mathrm{MAR}\right)$. Chemical Geology, 216, 329-352, doi: 10.1016/j.chemgeo.2004.11.015.

Cloutier, J., Piercey, S.J., Lode, S., Vande Guchte, M. \& Copeland, D.A. in press. Lithostratigraphic and structural reconstruction of the $\mathrm{Zn}-\mathrm{Pb}-\mathrm{Cu}-\mathrm{Ag}-\mathrm{Au}$ Lemarchant volcanogenic massive sulphide (VMS) deposit, Tally Pond group, central Newfoundland, Canada. Ore Geology Reviews. http://dx.doi.org/10.1016/j.oregeorev.2017.01.010

Copeland, D.A., Toole, R.M. \& Piercey, S.J. 2009. 10th Year Supplementary Assessment Report on Soil Sampling, Linecutting, Titan 24 Geophysical Surveying, Diamond Drilling and Petrography, Licence 8183M, South Tally Pond Property, Rogerson Lake Area, Newfoundland and Labrador, NTS 12A/10 and 12A/07. Newfoundland and Labrador Geological Survey Assessment File.

de Baar, H.J.W., German, C.R., Elderfield, H. \& van Gaans, P. 1988. Rare earth element distributions in anoxic waters of the Cariaco Trench. Geochimica et Cosmochimica Acta, 456 52, 1203-1219. 
DePaolo, D.J. 1981. Neodymium isotopes in the Colorado Front Ranges and crust-mantle evolution in the Proterozoic. Nature, 291, 193-196, doi: doi:10.1038/291193a0.

Dunning, G.R., Kean, B.F., Thurlow, J.G. \& Swinden, H.S. 1987. Geochronology of the Buchans, Roberts Arm, and Victoria Lake groups and Mansfield Cove Complex, Newfoundland. Canadian Journal of Earth Sciences, 24, 1175-1184.

\section{Dunning, G.R., Swinden, H.S., Kean, B.F., Evans, D.T.W. \& Jenner, G.A. 1991. A}

Cambrian island arc in Iapetus; geochronology and geochemistry of the Lake Ambrose volcanic belt, Newfoundland Appalachians. Geological Magazine, 128, 1-17.

Elderfield, H., Charnock, H., Lovelock, J.E., Liss, P.S. \& Whitfield, M. 1988. The oceanic chemistry of the rare-earth elements. Philosophical Transactions of the Royal Society of London, Series A: Mathematical and Physical Sciences, 325, 105-124.

Evans, D.T.W. \& Kean, B.F. 2002. The Victoria Lake Supergroup, central Newfoundland - its definition, setting and volcanogenic massive sulphide mineralization. Newfoundland and Labroador Department of Mines and Energy, Geological Survey, Open File NFLD/2790.

Fisher, C.M., McFarlane, C.R.M., Hanchar, J.M., Schmitz, M.D., Sylvester, P.J., Lam, R. \& Longerich, H.P. 2011. Sm-Nd isotope systematics by laser ablation-multicollectorinductively coupled plasma mass spectrometry: Methods and potential natural and synthetic reference materials. Chemical Geology, 284, 1-20.

Franklin, J.M., Sangster, D.M. \& Lydon, J.W. 1981. Volcanic-associated massive sulfide deposits. In: Skinner, B.J. (ed.) Economic Geology Seventy-Fifth Anniversary Volume. Society of Economic Geologists, 485-627.

Fraser, D., Giroux, G.A., Copeland, D.A. \& Devine, C.A. 2012. NI-43-101 Technical Report and Mineral Resource Estimate on the Lemarchant Deposit, South Tally Pond VMS Project, central Newfoundland, Canada for Paragon Minerals Corporation. National Instrument 43-101 Technical Report.

Fyffe, L.R., Barr, S.M., Johnson, S.C., McLeod, M.J., McNicoll, V.J., Valverde-Vaquero, P., van Staal, C.R. \& White, C.E. 2009. Detrital zircon ages from Neoproterozoic and Early Proterozoic conglomerate and sandstone units of New Brunswick and coastal Maine: implications for the tectonic evolution of Ganderia. Atlantic Geology, 45, 110144.

Gale, A., Langmuir, C.H. \& Dalton, C.A. 2014. The global systematics of Ocean Ridge Basalts and their origin. Journal of Petrology, 55, 1051-1082.

Galley, A.G., Hannington, M. \& Jonasson, I. 2007. Volcanogenic massive sulphide deposits. In: Goodfellow, W.D. (ed.) Mineral Deposits of Canada: A Synthesis of Major Deposit-types, District Metallogeny, the Evolution of Geological Provinces, and 
504 Exploration Methods. Special Publication 5, Mineral Deposits Division, Geological

505 Association of Canada, 141-161.

506

507

508

509

510

511

512

513

514

515

516

517

518

519

520

521

522

523

524

525

526

527

528

529

530

531

532

533

534

535

536

537

538

539

540

541

542

543

544

545

546

547

548

German, C.R. \& Von Damm, K.L. 2003. Hydrothermal Processes. Treatise on

Geochemistry. Pergamon, Oxford, 181-222.

Gibson, H.L., Allen, R.L., Riverin, G. \& Lane, T.E. 2007. The VMS model: Advances and application to exploration targeting. In: Milkereit, B. (ed.) Proceedings of Exploration 07: Fifth Decennial International Conference on Mineral Exploration, Toronto, ON, 717-730.

Gill, S.B. 2015. Mineralogy, metal zoning, and genesis of the $\mathrm{Zn}-\mathrm{Pb}-\mathrm{Ba}-\mathrm{Ag}-\mathrm{Au}$

Lemarchant volcanogenic massive sulfide (VMS) deposit. M.Sc. Thesis, Memorial University of Newfoundland.

Goldstein, S.L., O'Nions, R.K. \& Hamilton, P.J. 1984. A Sm-Nd isotopic study of atmospheric dusts and particulates from major river systems. Earth and Planetary Science Letters, 70, 221-237.

Grenne, T. \& Slack, J.F. 2003. Bedded jaspers of the Ordovician Lokken Ophiolite, Norway; seafloor deposition and diagenetic maturation of hydrothermal plume-derived silica-iron gels. Mineralium Deposita, 38, 625-639.

Hamilton, P.J., O'Nions, R.K., Bridgwater, D. \& Nutman, A. 1983. Sm-Nd studies of Archaean metasediments and metavolcanics from West Greenland and their implications for the Earth's early history. Earth and Planetary Science Letters, 63, 263-273.

Hannington, M.D., de Ronde, C.E.J. \& Petersen, S. 2005. Sea floor tectonics and submarine hydrothermal systems. In: Hedenquist, J.W., Thompson, J.F.H., Goldfarb, R.J. \& Richards, J.P. (eds.) Economic Geology: One Hundredth Anniversary Volume, 19052005. Society of Economic Geologists, Littleton, CO, USA, 111-142.

Hannington, M.D., Jonasson, I.R., Herzig, P.M. \& Petersen, S. 1995. Physical and chemical processes of seafloor mineralization at mid-ocean ridges. Geophysical Monograph, 91, 115-157.

Hekinian, R., Hoffert, M., Larqué, P., Cheminée, J.L., Stoffers, P. \& Bideau, D. 1993. Hydrothermal Fe and Si oxyhydroxide deposits from South Pacific intraplate volcanoes and East Pacific Rise axial and off-axial regions. Economic Geology, 88, 2099-2121.

Hibbard, J.P., van Staal, C.R. \& Rankin, D.W. 2007. A comparative analysis of preSilurian crustal building blocks of the northern and the southern Appalachian orogen. American Journal of Science, 307, 23-45, doi: 10.2475/01.2007.02.

549

Hollis, S.P., Cooper, M.R., Herrington, R.J., Roberts, S., Earls, G., Verbeeten, A., Piercey, S.J. \& Archibald, S.M. 2015. Distribution, mineralogy and geochemistry of 
550 silica-iron exhalites and related rocks from the Tyrone Igneous Complex: Implications

551 for VMS mineralization in Northern Ireland. Journal of Geochemical Exploration, 159,

552 148-168, doi: http://dx.doi.org/10.1016/j.gexplo.2015.09.001.

553

554

555

556

557

558

559

560

561

562

563

564

565

566

567

568

569

570

571

572

573

574

575

576

577

578

579

580

581

582

583

584

585

586

587

588

589

590

591

592

593

594

Huston, D., Relvas, J., Gemmell, J. \& Drieberg, S. 2011. The role of granites in volcanichosted massive sulphide ore-forming systems: an assessment of magmatic-hydrothermal contributions. Mineralium Deposita, 46, 473-507, doi: 10.1007/s00126-010-0322-7.

Huston, D.L., Pehrsson, S., Eglington, B.M. \& Zaw, K. 2010. The geology and metallogeny of volcanic-hosted massive sulfide deposits: Variations through geologic time and with tectonic setting. Economic Geology, 105, 571-591, doi: 10.2113/gsecongeo.105.3.571.

Ickert, R.B. 2013. Algorithms for estimating uncertainties in initial radiogenic isotope ratios and model ages. Chemical Geology, 340, 131-138, doi: 10.1016/j.chemgeo.2013.01.001.

Jenner, G.A. \& Swinden, H.S. 1993. The Pipestone Pond Complex, central Newfoundland; complex magmatism in an eastern Dunnage Zone ophiolite. Canadian Journal of Earth Sciences, 30, 434-448.

Keto, L.S. \& Jacobson, S.B. 1988. Nd isotopic variations of Phanerozoic palaeoceans. Earth and Planetary Science Letters, 90, 395-410.

Lode, S., Piercey, J.S. \& Devine, C.A. 2015. Geology, mineralogy, and lithogeochemistry of metalliferous mudstones associated with the Lemarchant volcanogenic massive sulfide deposit, Tally Pond belt, central Newfoundland. Economic Geology, 110, 1835-1859.

Lode, S., Piercey, S.J., Layne, G.D., Piercey, G. \& Cloutier, J. 2017. Multiple sulphur and lead sources recorded in hydrothermal exhalites associated with the Lemarchant volcanogenic massive sulphide deposit, central Newfoundland, Canada. Mineralium Deposita, 52, 105-128, doi: 10.1007/s00126-016-0652-1.

Lydon, J.W. 1984. Ore deposit models; 8, Volcanogenic sulphide deposits; Part I, A descriptive model. Geoscience Canada, 11, 195-202.

McCulloch, M.T. \& Wasserburg, G.J. 1978. Sm-Nd and Rb-Sr chronology of continental crust formation. Science, 200, 1003-1011.

McLennan, S.M., Bock, B., Hemming, S.R., Hurowitz, J.A., Lev, S.M. \& McDaniel, D.K. 2003. The roles of provenance and sedimentary processes in the geochemistry of sedimentary rocks. In: Lentz, D.R. (ed.) Geochemistry of Sediments and Sedimentary Rocks: Evolutionary Considerations to Mineral Deposit-Forming Environments.

595 

approaches to sedimentation, provenance, and tectonics. Special Paper Geological Society of America, 284, 21-40. and Nd-Sr isotopic composition of deep-sea turbidites; crustal evolution and plate tectonic associations. Geochimica et Cosmochimica Acta, 54, 2015-2050.

McNicoll, V., Squires, G., Kerr, A. \& Moore, P. 2010. The Duck Pond and Boundary Cu$\mathrm{Zn}$ deposits, Newfoundland: new insights into the ages of host rocks and the timing of VHMS mineralization. Canadian Journal of Earth Sciences, 47, 1481-1506.

Mills, R., Elderfield, H. \& Thomson, A. 1993. A dual origin for the hydrothermal component in a metalliferous sediment core from the Mid-Atlantic Ridge. Journal of Geophysical Research, 98, 9671-9681.

Mills, R.A. \& Elderfield, H. 1995. Hydrothermal activity and the geochemistry of metalliferous sediment. Geophysical Monograph, 91, 392-407.

Murphy, B.J., Waldron, J.W.F., Schofield, D.I., Barry, T.L. \& Band, A. 2014. Highly depleted isotopic compositions evident in Iapetus and Rheic Ocean basalts: implications for crustal generation and preservation. International Journal of Earth Sciences, 103, 1219-1232.

Nance, R.D., Murphy, J.B., Strachan, R.A., Keppie, J.D., Gutiérrez-Alonso, G., Fernández-Suárez, J., Quesada, C., Linnemann, U., D'Lemos, R. \& Pisarevsky, S.A. 2008. Neoproterozoic - early Palaeozoic tectonostratigraphy and palaeogeography of the peri-Gondwanan terranes: Amazonian v. West African connections. Geological Society of London, 297, 345-383.

Pearce, J.A. 1996. A user's guide to basalt discrimination diagrams. In: Wyman, D.A. (ed.) Trace element geochemistry of volcanic rocks: Applications for massive sulphide exploration. Geological Association of Canada, 79-113.

Peter, J.M. 2003. Ancient iron formations: their genesis and use in the exploration for stratiform base metal sulphide deposits, with examples from the Bathurst Mining Camp. In: Lentz, D.R. (ed.) Geochemistry of Sediments and Sedimentary Rocks: Secular Evolutionary Considerations to Mineral Deposit-Forming Environments. Geological Association of Canada, 145-176.

640

Piercey, S.J. 2007. Volcanogenic massive sulphide (VMS) deposits of the Newfoundland Appalachians: An overview of their setting, classification, grade-tonnage data, and unresolved questions. In: Pereira, C.P.G. \& Walsh, D.G. (eds.) Current Research. Geological Survey Branch, St. John's, NL, 169-178. 
641 Piercey, S.J., Squires, G.C. \& Brace, T.D. 2014. Lithostratigraphic, hydrothermal, and 642 tectonic setting of the Boundary volcanogenic massive sulfide deposit, Newfoundland 643 Appalachians, Canada: Formation by subseafloor replacement in a Cambrian rifted arc. 644 Economic Geology, 109, 661-687, doi: 10.2113/econgeo.109.3.661.

645 Pollock, J.C. \& Wilton, D.H.C. 2001. Metallogenic studies of the Tally Pond belt, Victoria Lake Group; trace-element geochemistry and lead-isotope data from the Exploits Subzone, Newfoundland. Report - Government of Newfoundland and Labrador. Dept. of Mines and Energy, Geological Survey, Report: 2001-1, pp.247-266.

Pollock, J.C., Wilton, D.H.C. \& van Staal, C.R. 2002. Geological studies and definition of the Tally Pond Group, Victoria Lake Supergroup, Exploits Subzone, Newfoundland Appalachians. Current Research - Newfoundland. Geological Survey Branch, Report: 021, pp.155-167.

660

661

662

663

664

665

666

Pollock, J.C., Hibbard, J.P. \& van Staal, C.R. 2011. A paleogeographical review of the peri-Gondwanan realm of the Appalachian orogeny. This article is one of a series of papers published in this CJES Special Issue: In honour of Ward Neale on the theme of Appalachian and Grenvillian geology. Canadian Journal of Earth Sciences, 259-288, doi: 10.1139/e11-049.

Raczek, I., Jochum, K.P. \& Hofmann, A.W. 2003. Neodymium and strontium isotope data for USGS reference materials BCR-1, BCR-2, BHVO-1, BHVO-2, AGV-1, AGV-2, GSP-1, GSP-2 and eight MPI-DING reference glasses. The Journal of Geostandards and Geoanalysis, 27, 173-179.

Rogers, N. 2004. Geochemical database, Red Indian Line project, central Newfoundland. In: Canada, G.S.o. (ed.), Open File 4605.

Rogers, N., van Staal, C.R., McNicoll, V., Pollock, J., Zagorevski, A. \& Whalen, J. 2006. Neoproterozoic and Cambrian arc magmatism along the eastern margin of the Victoria Lake Supergroup: A remnant of Ganderian basement in central Newfoundland? Precambrian Research, 147, 320-341.

Rogers, N., van Staal, C., Zagorevski, A., Skulski, T., Piercey, S.J. \& McNicoll, V. 2007. Timing and tectonic setting of volcanogenic massive sulphide bearing terranes within the Central Mobile Belt of the Canadian Appalachians. In: Milkereit, B. (ed.) Proceedings of Exploration 07: Fifth Decennial International Conference on Mineral Exploration, Toronto, ON, 1199-1205.

Rollinson, H.R. 1993. Using geochemical data: evaluation, presentation, interpretation. Longman, $352 \mathrm{p}$.

Rudnicki, M.D. 1995. Particle formation, fallout and cycling within the buoyant and nonbuoyant plume above the TAG vent field. Geological Society, London, Special Publication, 87, 387-396, doi: 10.1144/gsl.sp.1995.087.01.30. 

Ellsworth terrane, coastal Maine: Geochronology, geochemistry, and $\mathrm{Nd}-\mathrm{Pb}$ isotopic composition--Implications for the rifting of Ganderia. Geological Society of America Bulletin, 120, 1134-1158, doi: 10.1130/b26336.1.

Squires, G.C. \& Hinchey, J.G. 2006. Geology of the Tally Pond Volcanic Belt and Adjacent Areas (parts of NTS 12A/09 \& 12A/10). Map 2006-01.

Squires, G.C. \& Moore, P.J. 2004. Volcanogenic massive sulphide environments of the Tally Pond Volcanics and adjacent area; geological, lithogeochemical and geochronological results. In: Pereira, C.P.G., Walsh, D.G. \& Kean, B.F. (eds.) Current Research. Geological Survey Branch, St. John's, NL, 63-91.

Swinden, H.S. 1988. Introduction to volcanogenic sulphide deposits in Newfoundland. In: Swinden, H.S. \& Kean, B.F. (eds.) The volcanogenic sulphide districts of central Newfoundland. Geological Association of Canada, 1-26.

1991. Paleotectonic settings of volcanogenic massive sulphide deposits in the Dunnage Zone, Newfoundland Appalachians. Canadian Institute of Mining and Metallurgy Bulletin, 84, 59-89.

Swinden, H.S. \& Thorpe, R.I. 1984. Variations in style of volcanism and massive sulfide deposition in Early to Middle Ordovician island-arc sequences of the Newfoundland Central Mobile Belt. Economic Geology, 79, 1596-1619.

Tachikawa, K., Athias, V. \& Jeandel, C. 2003. Nedymium budget in the modern ocean and paleo-oceanographic implications. Journal of Geophysical Research, 108(C8), 3254.

Tanaka, T., Togashi, S., Kamioka, H., Amakawa, H., Kagami, H., Hamamoto, T., Yuhara, M., Orihashi, Y., Shigekazu, Y., Shimuzu, H., Kunimaru, T., Takahashi, K., Yanagi, T., Nakano, T., Fujimaki, H., Shinjo, R., Asahara, Y., Tanimizu, M. \& Dragusanu, C. 2000. JNdi-1: a neodymium isotopic reference in consistency with LaJolla neodymium. Chemical Geology, 168, 279-281.

Tivey, M.K. 2007. Generation of seafloor hydrothermal vent fluids and associated mineral deposits Oceanography, 20, 50-65.

Tosdal, R.M., Wooden, J.L. \& Bouse, R.M. 1999. Pb isotopes, ore deposits, and metallogenic terranes. Reviews in Economic Geology, 12, 1-28.

van Staal, C.R. \& Barr, S.M. 2011. Lithospheric architecture and tectonic evolution of the Canadian Appalachians and associated Atlantic margin. In: Percival, J.A., Cook, F.A. \& Clowes, R.M. (eds.) Chapter 2 Tectonic Styles in Canada: the LITHOPROBE Perspective. Geological Association of Canada, 3-55. 
van Staal, C.R., Barr, S.M. \& Murphy, J.B. 2012. Provenance and tectonic evolution of

734 Ganderia: Constraints on the evolution of the Iapetus and Rheic oceans. Geology, 40,

735 987-990, doi: 10.1130/g33302.1.

736

737

738

739

740

741

742

743

744

745

746

747

748

749

750

751

752

753

754

755

756

757

758

759

760

761

762

763

764

765

766

767

768

769

770

771

772

773

774

775

776

777

778

Von Damm, K.L. 1990. Seafloor hydrothermal activity; black smoker chemistry and chimneys. Annual Review of Earth and Planetary Sciences, 18, 173-204.

Williams, H. 1979. Appalachian Orogen in Canada. Canadian Journal of Earth Sciences, 16, 792-807.

Williams, H., Colman-Sadd, S.P. \& Swinden, H.S. 1988. Tectonostratigraphic subdivisions of central Newfoundland. Current Research, Part B. Geological Survey of Canada, Ottawa, ON, Canada, 91-98.

Winchester, J.A. \& Floyd, P.A. 1977. Geochemical discrimination of different magma series and their differentiation products using immobile elements. Chemical Geology, 20, 325-343.

Wood, S.A. \& Williams-Jones, A.E. 1994. The aqueous geochemistry of rare-earth elements and yttrium. Part 4. Monazite solubility and REE mobility in exhalative massive sulfide-depositing environments. Chemical Geology, 115, 135-162.

Zagorevski, A., van Staal, C.R., McNicoll, V.J. \& Rogers, N. 2007. Upper Cambrian to Upper Ordovician peri-Gondwanan island arc activity in the Victoria Lake Supergroup, central Newfoundland; tectonic development of the northern Ganderian margin. American Journal of Science, 307, 339-370.

Zagorevski, A., van Staal, C.R., Rogers, N., McNicoll, V.J. \& Pollock, J. 2010. Middle Cambrian to Ordovician arc-backarc development on the leading edge of Ganderia, Newfoundland Appalachians. Geological Society of America Memoir, 206, 367-396, doi: $10.1130 / 2010.1206(16)$. 


\section{Figure Captions}

780 Fig. 1. (a) Tectonostratigraphical assemblages with the main zones of the Newfoundland

781 Appalachians (Avalon, Gander, Dunnage, and Humber zones) and VMS occurrences

782 within the Notre Dame and Exploits subzones.

783 Notre Dame Subzone VMS: 1 - York Harbour; 2 - 8 - Baie Verte Belt Deposits; 9 - 12,

78446 - Springdale Belt Deposits; 13 - 29 Buchans-Roberts Arm Deposits.

785 Exploits Subzone VMS: 30 - 37 - Tulks Belt Deposits; Tally Pond Belt Deposits: 39 -

786 Lemarchant; 40 - Duck Pond; 41 - Boundary; 42 - 45 - Point Leamington Belt Deposits.

787 Modified after (Swinden, 1991) and Piercey (2007). (b) Geological map of the Tally

788 Pond volcanic belt. The Tally Pond group comprises the Lemarchant deposit and the

789 Duck Pond and Boundary mines. Figure after Copeland (2009) and Map 2006-01 from

790 Squires and Hinchey (2006) and Lode et al. (2017).

792 Fig. 2. Schematic illustration of the main aspects of hydrothermal circulation in

793 extensional tectonic environments. In the recharge zone seawater is entrained through

794 crustal and progressively heated during downward migration. Water-rock interactions

795 lead to loss of $\mathrm{Mg}^{2+}, \mathrm{SO}_{4}{ }^{2-}$, and $\mathrm{OH}^{-}$and $\mathrm{H}_{2} \mathrm{~S}$ is generated. These reactions produce $\mathrm{H}^{+}$

796 and create acidic fluids that leach metals out of rocks. In the reaction zone the highest

797 temperatures are reached and the hydrothermal fluids gain their geochemical signatures.

798 The hot fluids rise buoyantly up along synvolcanic faults and are expelled vie

799 hydrothermal plume into the ambient seawater. Figure modified after German and Von

800 Damm (2003) and Gibson et al. (2007). 
802 Fig. 3. Core photographs of the main Lemarchant mudstone types, tuff, and associated 803 felsic and mafic volcanic rocks of the Bindons Pond and Lake Ambrose formations, 804 respectively. (a) Finely laminated sulphide-rich EMS-type metalliferous mudstone with 805 cross-cutting stringer type veins and overlying massive sulphide mineralization. Section 806 101N, LM11-65, mudstone sample CNF30983, 160.7 m. (b) Proximal EMS-type 807 metalliferous mudstone associated with the Lemarchant Main Zone. Section 102+50N, 808 LM10-43, CNF20976, 202.3 m. (c) Proximal EMS-type metalliferous mudstone with 809 intercalated chert-apatite layers. Section 101N, LM07-13, CNF30954, 164.7 m. (d) FEM-

810 type mudstone associated with the Northwest Zone. Section 106N, LM08-28, CNF20986, 811240.6 m. (e) Sulphide-rich exhalative interflow mudstone. Section 101+25N, LM13-79, 812 CNF25072, $169.0 \mathrm{~m}$. (f) Lithic crystal vitric tuff that is intercalated with FEM-type 813 mudstone. Section 100+50N, LM13-77, CNF25065, 140.0 m. (g) Felsic to intermediate 814 volcanic rock of the Bindons Pond formation located in the North target. Section 108N, 815 LM11-49, 144.6 m. (h) Mafic to intermediate volcanic rock of the Lake Ambrose 816 formation located in the North target. Section 108N, LM11-49, $422.9 \mathrm{~m}$.

818 Fig. 4. (a) Spatial distribution of $\varepsilon N d$ for the EMS-, FEM-, and IFE-type mudstones and 819 tuff, as well as the Lemarchant felsic and mafic volcanic rock from this study. Sample 820 data do not show any spatial variations throughout the sections and/or with depth in the 821 stratigraphy in the Lemarchant area. $2 \sigma$ error bars calculated after algorithm from Ickert 822 (2013). (b) Resource map of the massive sulphides of the Lemarchant Main, 24 Zone, 823 and Northwest Zone. Massive sulphides are projected to the surface. Modified from the 824 resource map of Canadian Zinc Corporation. 
826 Fig. 5. (a) Diagram of $\varepsilon \mathrm{Nd}$ versus $\mathrm{Th} / \mathrm{Sc}$ ratio for the three main types of Lemarchant

827 mudstones (EMS, FEM, and IFE) and tuff. Also plotted are data from Rogers et al.

828 (2006) for felsic and mafic volcanic rocks of the Tally Pond belt and the

829 Crippleback/Sandy Brook Group crustal basement rocks. Mid Ocean Ridge Basalt

830 (MORB) field from data from Gale et al. (2014). Arc andesite field from data from

831 Hawkeswoth et al. (1979). All data re-calculated for $\varepsilon \mathrm{Nd}_{513}$. Diagram modified after

832 McLennan et al. (1993). (b) Plot of $f^{\mathrm{Sm} / \mathrm{Nd}}$ versus $\varepsilon N d$ for the EMS-, FEM-, and IFE-type

833 mudstones and tuff, as well as the Lemarchant felsic and mafic volcanic rock from this

834 study. Also plotted are data from Rogers (2004) and Rogers et al. (2006) for felsic and

835 mafic volcanic rocks of the Tally Pond belt, a felsic volcanic rock samples from the

836 unmineralized Upper Block at Duck Pond and a sample from the Mineralized Block at

837 Duck Pond from data from McNicoll et al. (2010), and the Crippleback/Sandy Brook

838 Group crustal basement rocks. Diagram modified after McLennan et al. (1993).

839

840 Fig. 6. (a) and (b) $\mathrm{Zr} / \mathrm{Ti}$ versus $\mathrm{Nb} / \mathrm{Y}$ and $\mathrm{Nb}$ versus $\mathrm{Y}$ discrimination diagrams for

841 volcanic rocks after Winchester and Floyd (1977) and Pearce (1996) for the Lemarchant

842 felsic and mafic volcanic rocks from this study and from data from Rogers (2004) and

843 Rogers et al. (2006). Additionally, data fields for felsic, intermediate, and mafic volcanic

844 rocks was added (Cloutier, in press). Data from Rogers (2004) and Rogers et al. (2006)

845 was also used to plot the Crippleback Lake/Sandy Brook Group crustal basement rocks. 
847 Fig. 7. Model displaying the Cambrian Tally Pond belt with juvenile Nd signatures that is

848 built upon the Ganderian and Gondwanan Amazonian rifted crustal basement with

849 evolved Nd signatures. (a) Early stages of arc rifting with felsic volcanism and formation

850 of massive sulphides and genetically associated metalliferous mudstones. Scavenged and

851 detrital juvenile and evolved $\mathrm{Nd}$ is archived in archiving in the metalliferous mudstones

852 resulting in mixed signatures. (b) Final stages of arc rifting and emplacement of mafic

853 volcanic rocks that form the hanging wall to the Lemarchant VMS deposit.

854

855 Fig. 8. Diagram of $\varepsilon N d$ versus age for Tally Pond belt mudstone and volcanic rock

856 samples from this study and from Rogers (2004), Rogers et al. (2006), and McNicoll et

857 al. (2010). The field for Ganderian Neoproterozoic rocks is from Rogers et al. (2006).

858 Fields for the Mesoproterozoic Amazonian crust, the Transamazonian crust, and the West

859 African Craton are from Satkoski et al. (2010) and references therein. Depleted mantle

860 evolution curve is from dePaolo (1981). CHUR $=$ Chondrite uniform reservoir.

861

862

863

864

865 
Table 1. Sm-Nd isotope data for Lemarchant exhalites and bimodal volcanic rocks

\begin{tabular}{|c|c|c|c|c|c|c|c|c|c|c|c|c|c|}
\hline \# & e & $\begin{array}{c}\text { Section } \\
(\mathbf{N})\end{array}$ & $\begin{array}{c}\text { UTM } \\
\text { NAD27 Z21 - } \\
\text { East }\end{array}$ & $\begin{array}{c}\text { UTM } \\
\text { NAD27 Z21 } \\
\text { North }\end{array}$ & h & $\begin{array}{c}\text { Rock } \\
\text { type }\end{array}$ & $\begin{array}{c}{ }^{143} \mathrm{Nd} /{ }^{144} \mathrm{Nd} \\
\text { Rock t }{ }_{0}{ }^{*}\end{array}$ & $\begin{array}{c}{ }^{147} \mathrm{Sm} /{ }^{144} \mathrm{Nd} \\
\text { Rock } \mathrm{t}_{0}\end{array}$ & $\begin{array}{c}{ }^{143} \mathrm{Nd} /{ }^{144} \mathrm{Nd} \\
\text { Rock t } \\
513\end{array}$ & 13 & $\sigma^{*}$ & d & $\mathbf{T}_{\mathrm{DM}}$ \\
\hline $5062 b$ & & & & & & & & & 72 & & & & 171 \\
\hline & & & & & & & & & 36 & & & & 4.5 \\
\hline & & & & 3 & & EMS & 2065 & 0 & 11692 & 67 & & & 309.6 \\
\hline & & & 4 & & & EMS & 12213 & & 511763 & & & & 1742.9 \\
\hline & & & 20 & & & IFE & 512372 & & 86 & & & & 1702.6 \\
\hline & & & 537 & & & EMS & & 00 & & & & & 634.2 \\
\hline & & & 537 & & & IFE & & & & -5.970 & & & 3047.8 \\
\hline & & & 537 & 37 & & FEM & & & & -3.219 & & & 2163.7 \\
\hline & & & 537 & 96 & & EMS & & & & -4.078 & & & 698.4 \\
\hline $\mathrm{CNF}$ & LM0 & 500 & 53750 & .71 & & EMS & 122 & 20500 & 717 & -5.084 & 0.280 & & 1813.0 \\
\hline $002 \mathrm{~A}$ & M13 & 600 & 5375 & 520599.30 & 294.2 & Tuff & 0.512105 & 125000 & 0.511685 & -5.711 & 0.288 & -0.364 & 1816.2 \\
\hline CNF- & M11 & 0800 & 5375314.26 & 521092.55 & 158.7 & FEM & 0.512231 & 0.135700 & 0.511775 & -3.953 & 0.281 & -0.310 & 1745.0 \\
\hline $\mathrm{CNl}$ & 41 & 800 & 5375 & 52109 & & Felsic & 0.512477 & 0.142800 & 0.511997 & 0.386 & 0.293 & -0.274 & 1472.3 \\
\hline CNF-20913 & LM11-49 & 10800 & 5375314.26 & 521092.55 & 422.9 & Mafic & 0.512600 & 0.164400 & 0.512048 & 1.371 & 0.308 & -0.164 & 1736.3 \\
\hline
\end{tabular}

EMS = Exhalative mudstone immediately associated with massive sulphides $\quad \nabla$ Calculated using the values of ${ }^{143} \mathrm{Nd} /{ }^{144} \mathrm{Nd}=0.513163 \mathrm{and}{ }^{147} \mathrm{Sm} /{ }^{144} \mathrm{Nd}=$

(within $5 \mathrm{~m}$ ) and felsic and mafic volcanic rocks; FEM = Exhalative mudstone $\quad 0.2137$ for the depleted mantle reservoir (Goldstein et al.1984)

associated with felsic and mafic volcanic rocks; IFE = Interflow mudstone within

mafic volcanic rocks.

$\$ 2 \sigma$ calculated using the algorithm after Ickert (2013)

*Calculated using ${ }^{143} \mathrm{Nd} /{ }^{144} \mathrm{Nd}$ of chondrite uniform reservoir $(\mathrm{CHUR})=$

0.512638 and ${ }^{147} \mathrm{Sm} /{ }^{144} \mathrm{Nd}$ CHUR today $=0.1967$ from Rollinson $(1993)$ 

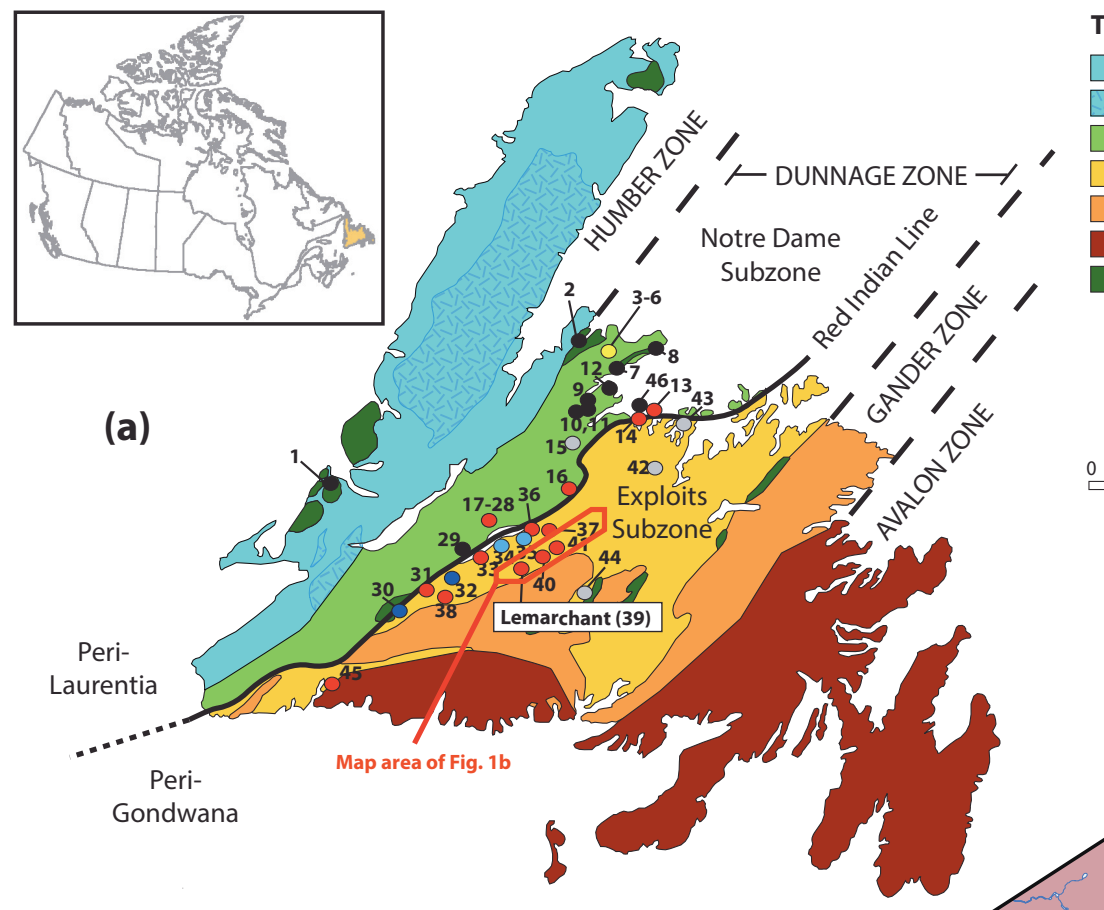

\section{Tectonostratigraphic Assemblages}

$\square$ Humber Zone

Humber Zone - Grenvillian inliers

Dunnage Zone - Notre Dame Subzone

Dunnage Zone - Exploits Subzone

Gander Zone

Avalon Zone

Ophiolitic Rocks

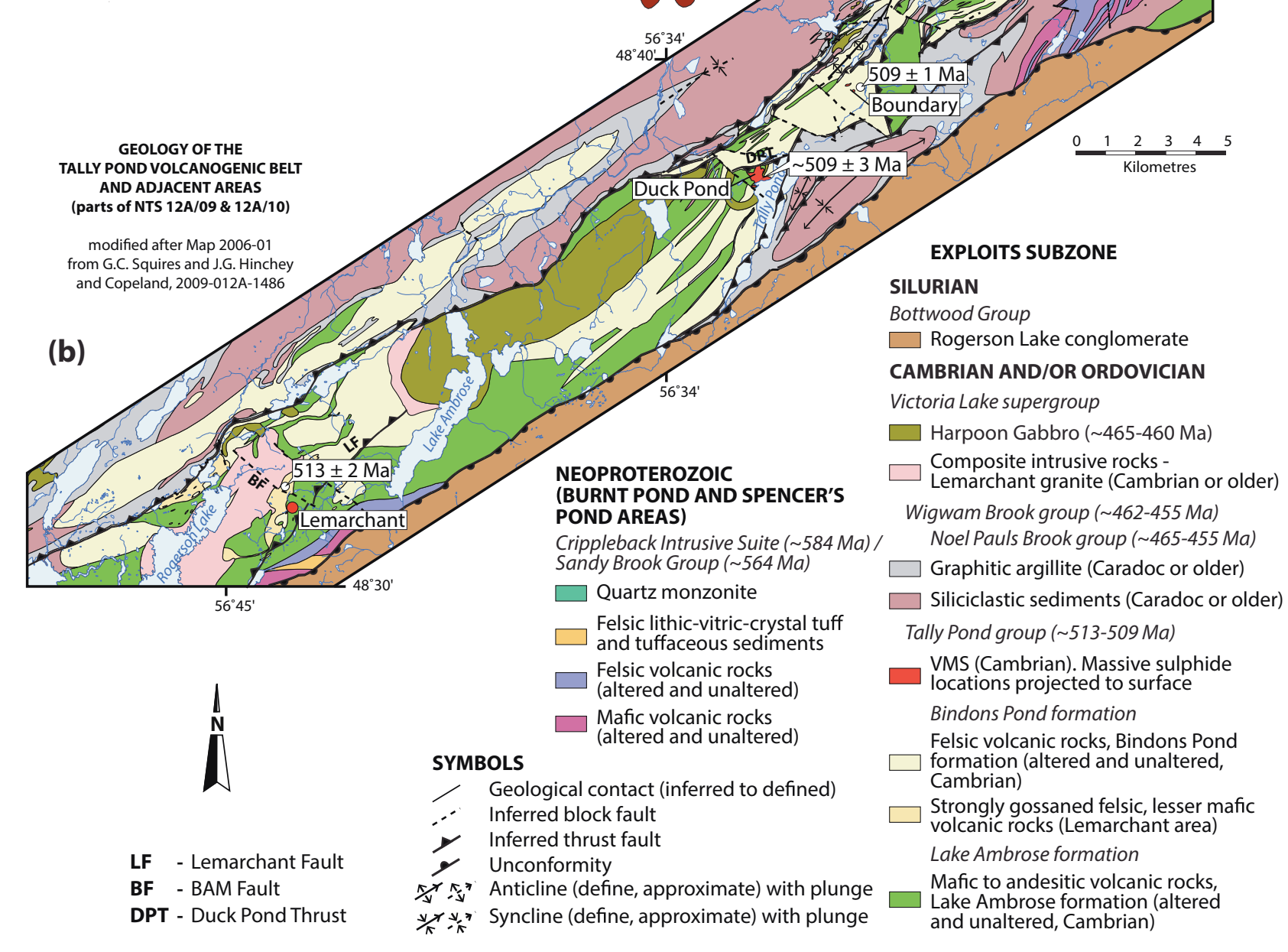


Fig. 2

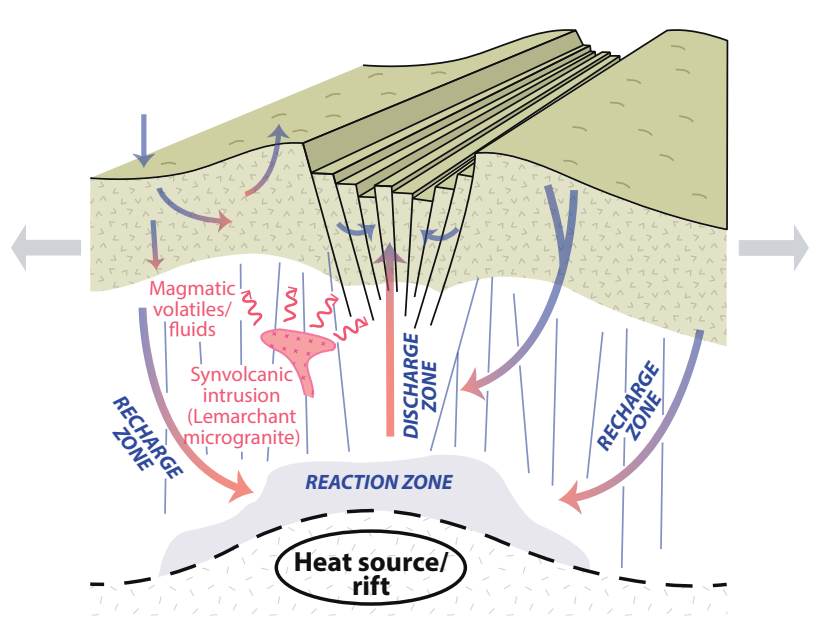


Fig. 3
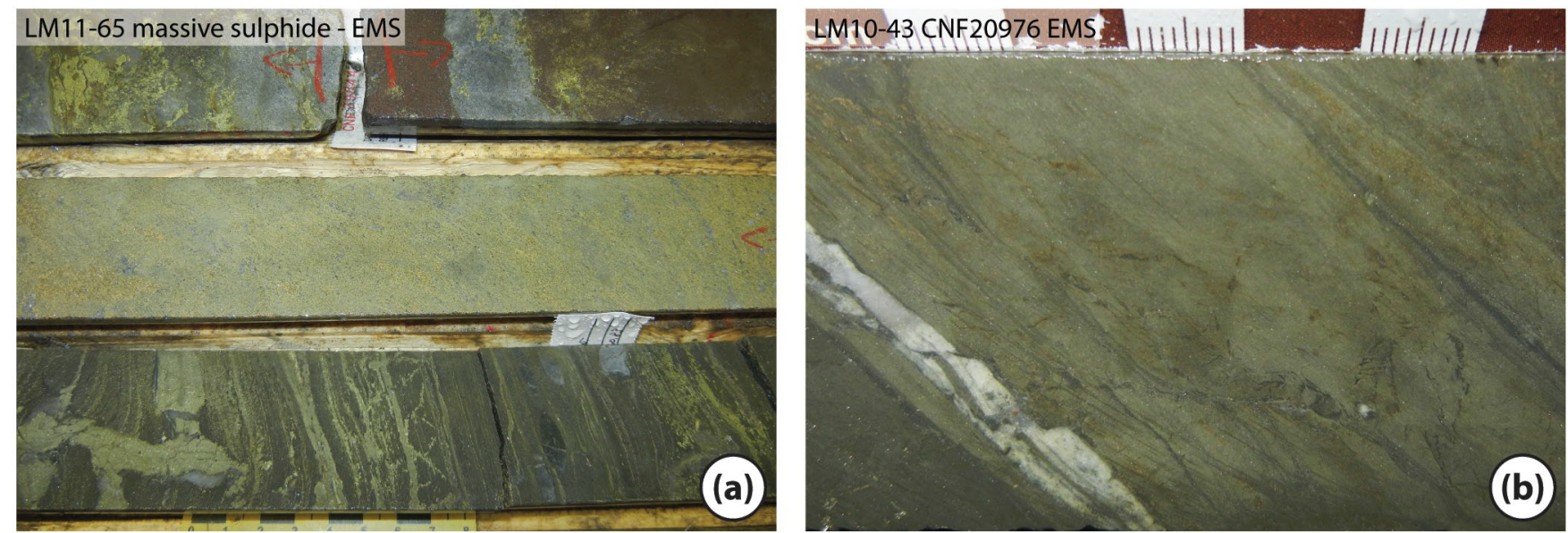

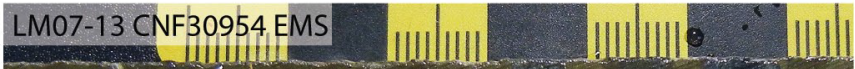

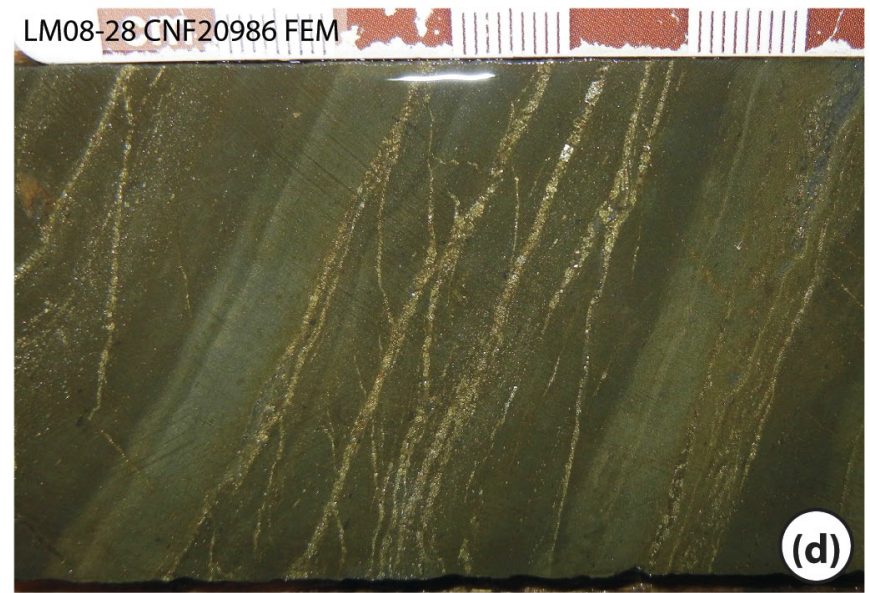$$
\text { L }
$$

(c) LI

(e)

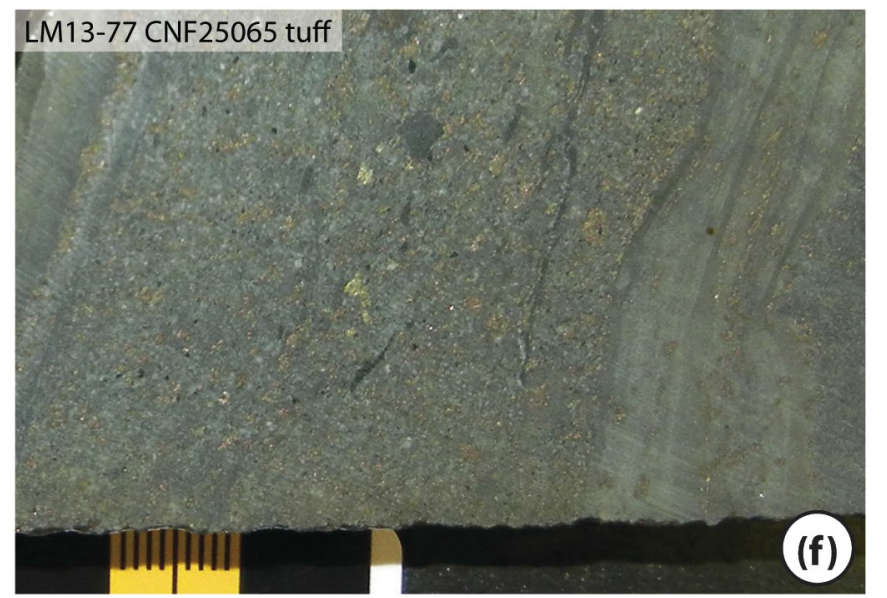

LM11-49 CNF20910 felsic |||||||| $\mid$ |||||||||

\section{LM11-49 CNF20913 mafic}
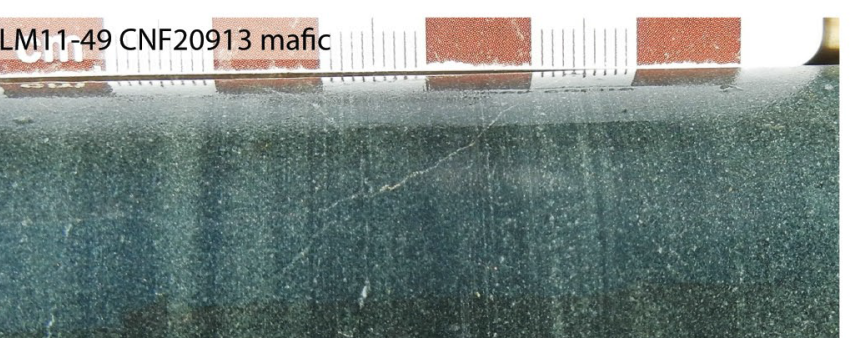


\section{Lode, Stefanie Fig. 4}

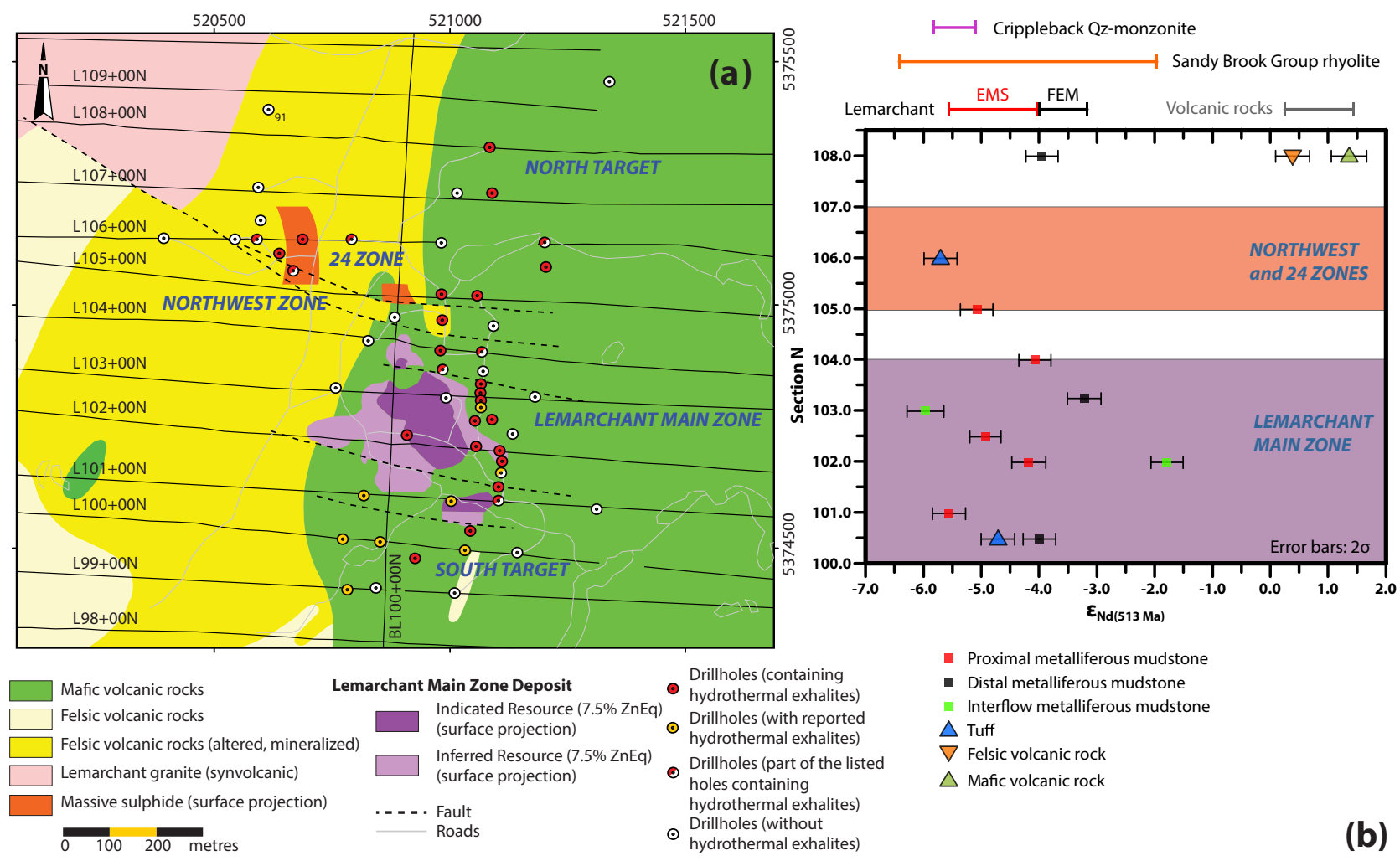


Fig. 5
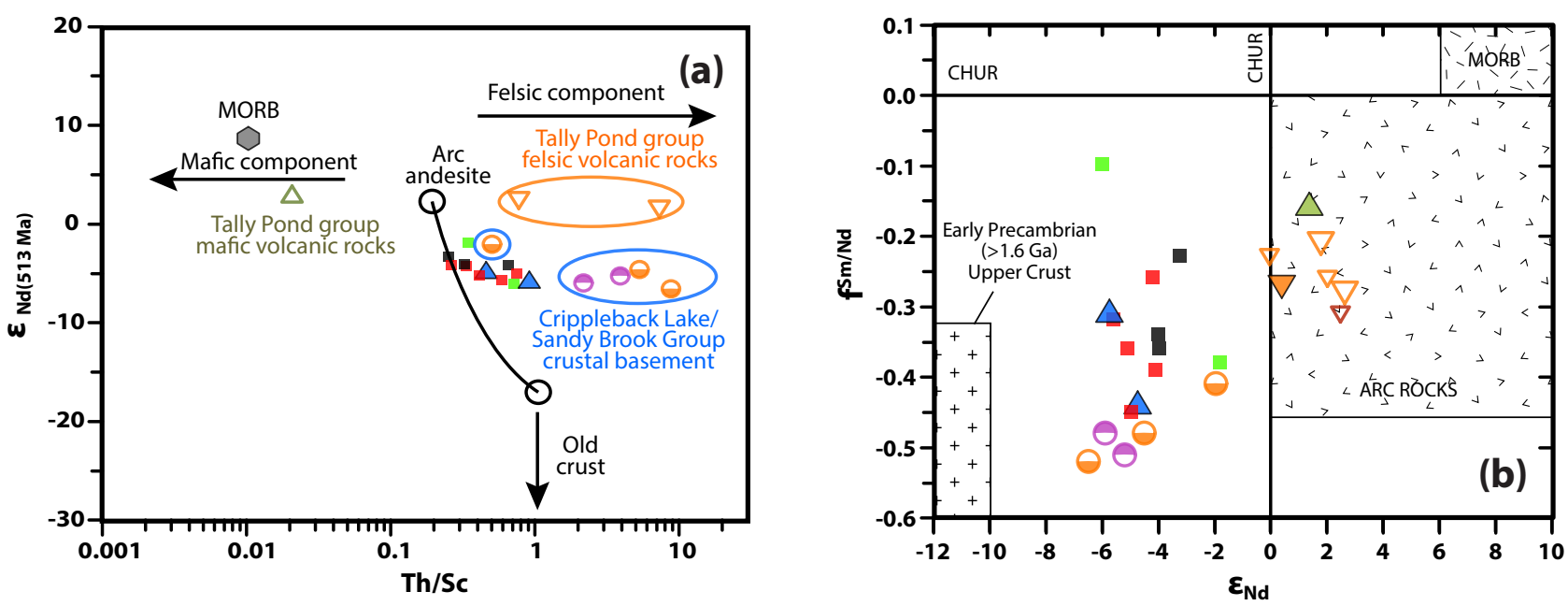

Data from this study $\left(\varepsilon \mathrm{Nd}_{513}\right)$

- Lemarchant proximal mudstone

- Lemarchant distal mudstone

- Lemarchant interflow mudstone $\triangle$ volcanic rock, Lemarchant

Lemarchant felsic to intermediate volcanic rock,

Data from Rogers (2004) and Rogers et al. (2006)

Data from McNicoll et al. (2010)

$\triangle$ Tally Pond belt Lake Ambrose basalt $\left(\varepsilon \mathrm{Nd}_{511}\right)$

Duck Pond Upper Block

Tally Pond belt Bindite and dacite $\left(\varepsilon \mathrm{Nd}_{513}\right)$

Lemarchant mafic to intermediate

Sandy Brook Group rhyolite $(\varepsilon N d)$

$\nabla$ Duck Pond Mineralized Block

Crippleback Qz-monzonite ( $(\varepsilon N d)$ ore horizon (felsic volcanic rocks) $\left(\varepsilon \mathrm{Nd}_{509}\right)$

$\triangle$ Lemarchant tuff 
Fig. 6

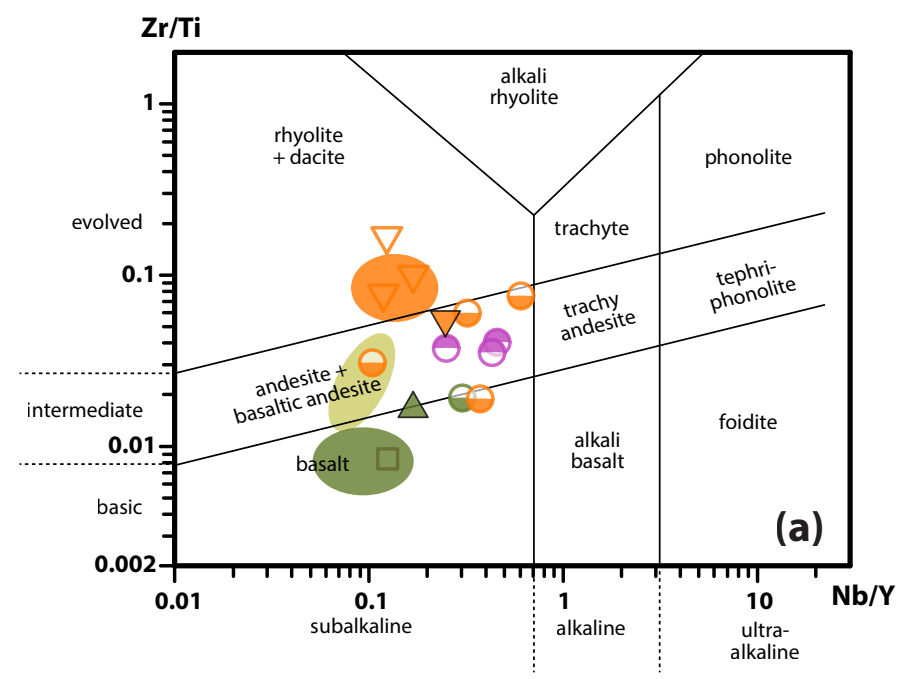

Data from this study

$\nabla$ Lemarchant felsic to intermediate volcanic rock

Lemarchant mafic to intermediate volcanic rock, Lemarchant

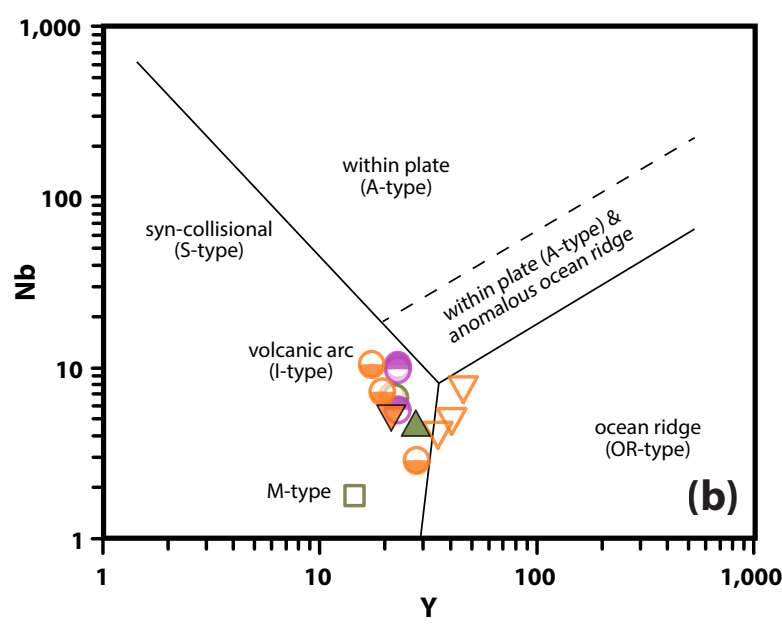

Data from Rogers (2004) and Rogers et al. (2006)

$\square \quad$ Tally Pond belt Lake Ambrose basaltic andesite

$\nabla$ Tally Pond belt Bindons Pond Fm rhyolite

Sandy Brook Group rhyolite

Sandy Brook Group basalt

Crippleback Qz-monzonite 


\section{Lode, Stefanie Fig. 7}

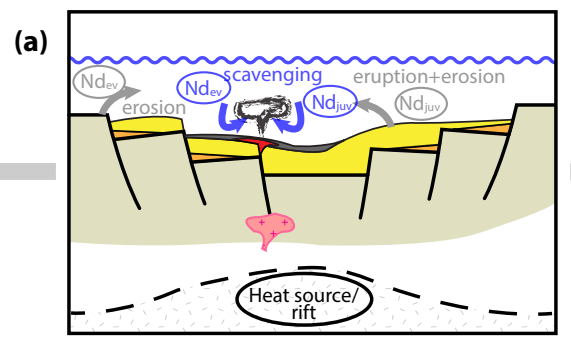

$>$ Cambrian bimodal Tally Pond volcanic belt built upon Ganderian rifted arc and older Gondwanan/Amazonian crustal basement.

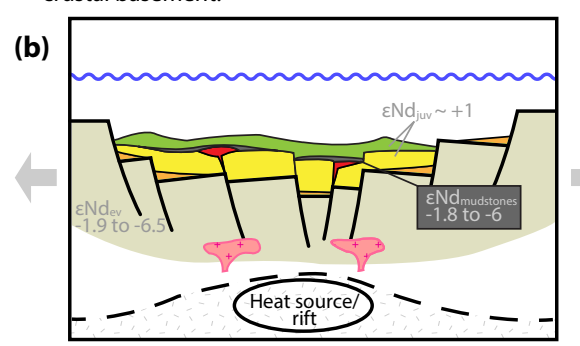

$>$ Felsic volcanism with hydrothermal activity and formation of massive sulphides and associated metalliferous mudstones. $>$ Erosion of Neoproterozoic and older crustal basement rocks releases evolved $\mathrm{Nd}$ into

seawater.

$>$ Erosion of Cambrian Tally Pond belt volcanic rocks releases juvenile $\mathrm{Nd}$ into seawater. $>$ Detritally derived and scavenged $\mathrm{Nd}_{\mathrm{ev}+\mathrm{juv}}$

from seawater results in metalliferous

mudstones with mixed $\mathrm{Nd}$ isotopic signatures.
Mafic volcanic rocks

(Lake Ambrose formation)

Metalliferous mudstones

Massive sulphides

Felsic volcanic rocks

(Bindons Pond formation)

Volcaniclastic sediments

Crippleback Lake Intrusive Suite/

Sandybrook Group crustal

Synvolcanic intrusion 


\section{Fig. 8}

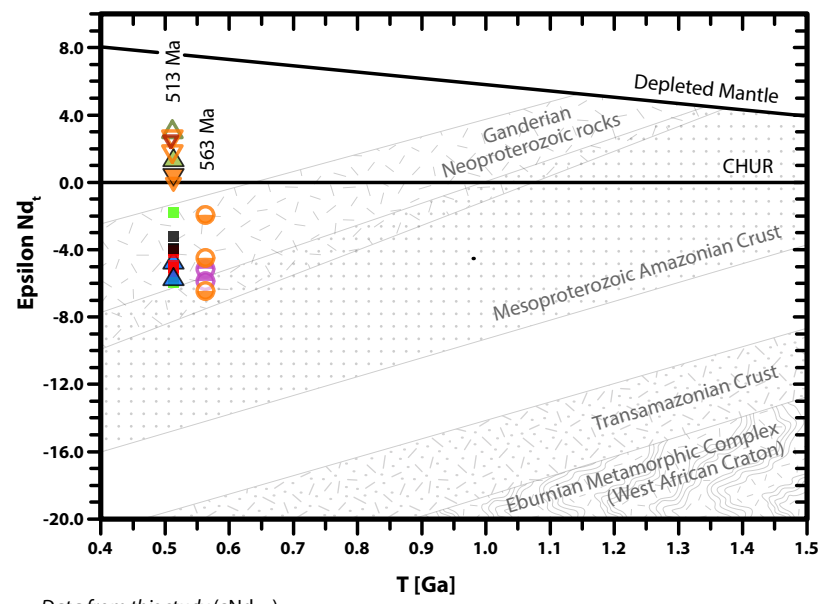

Data from this study $\left(\varepsilon \mathrm{Nd}_{513}\right)$

- Lemarchant proximal mudstgneemarchant felsic to intermediate

- Lemarchant distal mudstone volcanic rock

$\triangle$ Lemarchant tuff

Data from Rogers (2004) and Rogers et al. (2006)

$\triangle$ Tally Pond belt Lake Ambrose basalt $\left(\varepsilon \mathrm{Nd}_{511}\right)$

$\nabla$ Tally Pond belt Bindons Pond Fm rhyolite $\left(\varepsilon \mathrm{Nd}_{511}\right)$

Sandy Brook Group rhyolite $(\varepsilon N d)$

Crippleback Qz-monzonite $(\varepsilon N d)$

Data from McNicoll et al. (2010)

Duck Pond Upper Block

rhyolite and dacite $\left(\varepsilon \mathrm{Nd}_{513}\right)$

Duck Pond Mineralized Block

ore horizon (felsic volcanic rocks)

$\left(\varepsilon \mathrm{Nd}_{509}\right)$ 